Araştırma Makalesi

\title{
Y Kuşağının İnternetten Alışverişe Yönelik Tutumları: Nicel Bir Araştırma
}

\author{
Hidaye Aydan (Silkü) Bilgilier (Dr. Öğr. Üyesi) \\ Ege Üniversitesi İletişim Fakültesi \\ hidaye.aydan.bilgilier@ege.edu.tr \\ Orcid: 0000-0001-5337-9243
}

Başvuru Tarihi: 15.11.2018

Yayına Kabul Tarihi: 03.01.2019

Yayınlanma Tarihi: 21.01.2019

\section{Öz}

$\mathrm{Bu}$ araştırmanın amacı, Y kuşağının internetten alışverişe yönelik tutumlarının ne yönde olduğunu belirlemektir. Bu amaç doğrultusunda çalışmada 1980-2000 yılları arasında doğan ve Y kuşağı olarak adlandırılan yeni nesil gençlerin internetten alışverișe yönelik tutumlarının yönünü belirlemek üzere bir araștırma planlanmıștır. Araștırma örneklemi, Y kuşağını temsilen İletişim Fakültesi, Halkla İlişkiler ve Tanıtım, Reklamcılık, Radyo, Televizyon ve Sinema, Gazetecilik Bölümlerinin 1. Öğretiminde okuyan lisans öğrencilerinden olmak üzere toplam 547 öğrenciden oluşmaktadır (n=547). Araştırmada Silkü (2009) tarafından geliştirilen "İnternette Alışverişe Yönelik Tutum Ölçeği" (İAYTÖ) ile kişisel bilgi formu uygulanmıştır. Araștırma verilerine; frekans, tek yönlü varyans analizi, t testi, çoklu karşılaştırma testi analizleri yapılmıştır. Araştırma bulguları, Y kuşağını temsil eden İletişim Fakültesi lisans öğrencilerinin internetten alışverişe yönelik tutumlarının olumlu yönde olduğunu ve bu durumun bölümlere, yaşa, cinsiyete, aylık gelir durumuna, internetten alışveriş yapma durumuna, internetten alışveriş yapma sıklığına, internetten ürün/hizmet satın alma yılına, alışveriş ödeme şekline göre pozitif yönde değiştiğini ortaya koymaktadır.

Anahtar Kelimeler: İnternetten Alışverişe Yönelik Tutum, Y kuşağl, İletişim Fakültesi Lisans Öğrencileri. 


\title{
The Attitudes of Generation Y Towards Online Shopping: A Quantitative Study
}

\author{
Hidaye Aydan (Silkü) Bilgilier (Asst. Prof. Dr.) \\ Ege University Faculty of Communication \\ hidaye.aydan.bilgilier@ege.edu.tr \\ Orcid: 0000-0001-5337-9243
}

Date Received: 15.11 .2018

Date Accepted: 03.01.2019

Date Published: 21.01.2019

\begin{abstract}
The aim of this study is to determine the attitudes of Generation Y towards Online Shopping. In accordance with this objective, a quantitative research has been planned to be conducted for the young generation, born between 1980 and 2000, and also known as Generation Y, to understand how they approach to Online Shopping. A total of 547 1st education undergraduate students from the Departments of Public Relations and Publicity, Advertising, Radio-Television and Cinema, and Journalism of the Faculty of Communication at Ege University, representing the Generation $Y(n=547)$, constitute the sample for this study. To collect data, an "Attitude Scale Towards Online Shopping" developed by Silkü (2009) and a personal information questionaire have been used, and to analyze data obtained, frequency, one-way ANOVA, multiple comparisons and t tests have been employed. The research findings have revealed that the attitudes of the Faculty of Communication undergraduate students towards Online Shopping are positive, and change in a positive way according to their departments, ages, sexes, monthly incomes, the state and frequency of online shopping, the year of buying goods/services, and the method of payment.
\end{abstract}

Keywords: Attitude towards Online Shopping, Generation Y, Faculty of Communication Undergraduate Students. 


\section{Giriş}

İnternetin gelişmesiyle birlikte işletmeler pazarlama alanında ürünlerini tanıtma aşamasında eșit rekabet gücüne sahip olmuşlardır. İnternet üzerinden pazarlama, birçok işletme tarafından hem ucuz hem de yaygın bir pazarlama aracı olarak kullanılmaya başlamıştır (Erdoğan ve Torun, 51). Bazı araştırmacılar, (Hoffman ve Novak, 1995; Timmers, 2000) internetin pazarlama iletişimi üzerinde önemli bir etkisi olan bazı özelliklerinin olduğunu iddia etmektedir. Bunlar: 24 saat çevirimiçi; multi medya; aynı anda her yerde; küresel kullanabilirlik; interaktif; bire bir ve/ veya mikro pazarlama; entegrasyon şeklinde sıralanabilir. İnternette pazarlama; pazarlama hedeflerine ulaşmak ve modern pazarlama anlayışını (Pazar/müșteri yönelimlilik) desteklemek için internet ve internete ilişkin dijital teknolojinin kullanımıdır (Tağıyev, 2005, 30). Dijital pazarlama kanalı olarak kullanılan bu teknolojik alanlar, kurumlar açısından üretilen içeriğe ulaşma, bilgi ve haber alma konularında öncelikli başvurulan yeni medya araçlarıdır (Bulunmaz, 2016, 358). İnternet pazarlamacılığına yönelik yeni stratejilerin, hedeflere odaklanmanın, iyi yönetilen web sitelerine dayalı, özgünlüğün ve tanıtımın vurgulandığı ürün stratejilerinin yer alması önemlidir. İnternet, küresel bir mecradır, onu kullanan şirketler uluslararası izleyiciyi potansiyel müșteri olarak ele alınmaktadır (Lagrosen, 2005, 63). İşletmeler, internet yoluyla hem işletmeden işletmeye hem de işletmeden tüketiciye yönelik pazarlama faaliyetlerini daha etkin, hızlı ve global boyutta gerçekleştirmektedir. Teknolojik gelişmeler, sadece işletmeleri değil aynı zamanda tüketicilerin yapısında da değișikliklere neden olmuştur. Tüketici davranışı teknolojik gelişmelerle birlikte sürekli değişim göstermektedir. Özellikle internetin yaygınlaşarak günlük hayatımızın her alanında yer edinmesi, tüketicilerin ürün ve hizmet taleplerine yeni boyutlar kazandırmıștır (Gümül, 2015, 1). Günümüz tüketicisi daha fazla talep eden, daha fazla bilgi isteyen ve bireysel hareket eden bir yapıya bürünmüștür (Erdoğan ve Torun, 2009, 51). İnternet yoluyla alıșveriş yapan tüketici çok daha hızlı olarak ürün özellikleri, ürün alternatifleri, fiyatları ve dağıtım-teslimat konularında bilgi sahibi olmakta ve karşılaştırmaya gidebilmekte bu sayede de zamandan tasarruf sağlamakta ve 24 saat kesintisiz eğlenceli alışveriş imkanı yakalamakta ve son olarak da coğrafi sınırlarını genişleterek alışveriş yapabilmektedir (Tağıyev, 2005, XI; Erdoğan ve Torun, 2009, 51; Jusoh ve Ling, 2012 , 223). İnternette alışverişin yaygınlaşmasının en önemli sebeplerinden biri de internetin tüketicileri merkeze alarak, kișisel, hızlı ve seçenekli tüketimi sunmasıdır. Bir diğer sebebi ise tüketicilerin internet ile pazarlama sürecini kendileri başlatabilme ve yönetebilme imkanı yakalamalarıdır (Gül ve Boz, 2012, 6). Bu durum tüketicilerin satın alma süreçlerindeki kontrollerini ve avantajlarını arttırmaktadır. Ayrıca internet üzerinden tüketici talep ettiği ürün ya da hizmeti bireyselleştirerek sipariş verebilmektedir. Diğer bir avantaj olarak da aynı anda ürün ve fiyat karşılaştırması yapabilerek alışverișe harcadığı zamanın yerine daha hızlı alışveriş yapabilmektedir. Bütün bu sözü edilen avantajlar nedeniyle tüketicinin internetten alışverişe yönelik tutumları da olumlu yönde gelişmiştir (Özcan, 2010, 32).

Buna karşın bazı güvensizlik problemleriyle tüketici internetten alışverișe olumsuz tutum da sergileyebilmektedirler. Tutum, uygun olan ya da olmayan tavır biçiminde bir davranışı değerlendirme eğilimi olarak tanımlanmaktadır (Naadem vd., 2015, 433). Tüketici çalışmalarında tutum, merkezi rolü içerir. Çünkü, duyguları, düşüncüleri ve tüketicinin karar vermesini etkiler. Davranıșa karşı tutum davranışsal niyet üzerinden doğrudan bir etkiye sahiptir. Tüketicilerin tutumu, tüketicilerin satın 
alma isteğini etkileyen ve doğrudan etkilenen faktördür. Davranışa yönelik tutumun belirli bir davranışla güçlü bir șekilde ilișkili olduğu bulunmuştur (Naadem vd., 2015, 433; Jun ve Jaafar, 2011, 123). Tüketicilerin internetten alışverișe yönelik tutumlarını etkileyen faktörler ise şu şekilde sıralanmaktadır: Kullanabilirlik, güvenlik, gizlilik, satış sonrası servis, pazarlama karması ve itibar. Bu faktörlere kısaca değinmekte fayda vardır (Jun, ve Jaafar, 2011, 124):

*Algılanan Kullanabilirlik: Bir web sitesinin kullanıcılarının işlevlerini kolayca ve uygun bir şekilde kullanmalarını kolaylaştırması anlamına gelmektedir. Diğer bir ifadeyle, web kullanabilirliği doğru bir tasarım ile mümkündür. Tasarım, müşterilerin hızlı bir biçimde işlemlerini gerçekleştirebilecekleri basitlikte olmalıdır. Bu nedenle, web sitesinin kullanabilirliği, çevrimiçi tüketiciler üzerinde önemli bir etkiye sahiptir. Çok sayıdaki araştırmalar kriter olarak şu faktörleri sıralamıştır: Kullanım kolaylığı, yanıt süresi, gezinme, etkileşim, tasarım gibi web sitelerinin kullanabilirliğini ölçmek, kolaylık, öğrenebilirlik, verimlilik, saha uygunluğu ve erişebilirlik.

*Algılanan Güvenlik: Web'in hassas bilgileri iletmek için ne derece güvenli olduğuyla ilgilidir. $\mathrm{Bu}$ durum çevrimiçi satın alma niyeti ile pozitif ilişkilidir. Güvenlik, tüketicilerin e-satın almayı kullanmalarında tereddütlerine ya da korkularına neden olarak internete yönelik alışveriş tutumları üzerinde baskın bir etki yaratmaktadır.

*Algılanan Gizlilik: Çevrimiçi gizlilik sorunları genellikle bir web sitesindeki kişisel bilgilerin toplanması ve yayılması biçiminde mahremiyetin korunamaması şeklinde ortaya çıkmaktadır. Çevrimiçi gizliliğin korunması çok zordur ve bu durum tüketicilerin çevrimiçi alışverişi reddetmesi şeklinde olumsuz bir tutum geliştirmelerine neden olabilir.

*Satış Sonrası Hizmet Kalitesi Algısı: Müşteriye satın alma ödemesi sonrasında ürün ya da hizmet teslimatıdır. Satış sonrası hizmetler iki şekilde gerçekleşir. Birincisi, beklenen hizmetleri kurulum, eğitim, yazılı talimatlar, bakım ve yükselme gibi müşteri planları. İkincisi ise, beklenmedik hizmetler olarak: tamirat, iade ve değiștirmeler gibi satılmış olan ürünlerin bakımıdır. Sözü edilen satış öncesi ve sonrası hizmetler, çevrimiçi müşteri memnuniyeti üzerindeki etkisi son derece önemlidir.

*Algılanan Pazarlama Karması: Pazarlamanın 4P'si olarak adlandırılan; ürün, fiyat, promosyon ve yer tüketicilerin davranışlarını ve sonuçlarını etkileyecek araçlar olarak kabul edilmektedir.

Tüketici olarak Y kuşağı üyeleri sabırsızdırlar ve hızlı bilgiye ihtiyaç duyarak anlık memnuniyete ulaşırlar. Son yıllarda kişiselleştirilmiş hizmetler ve özelleștirilmiş ürünlerin ulaşılabilirliğinin artmasından fayda sağlamışlardır (Corodenau, 2015). Y kuşağı 1980'den 1999'a kadar olan genç kuşağı kapsamaktadır (Lissitsa ve Kol, 2016, 304). "Milenyum Kuşağı”, "İnternet Kuşağı", "Dijital Kullanıcılar” ve "C Kuşağı" olarak da bilinen Y kuşağı, (18-34) yaş grubunu kapsamaktadır. Teknoloji ve internet ile büyüyen bu nesil son derece sosyal, teknoloji okuryazarı ve medya/teknoloji meraklısıdır. İnternet ve mobil servislerin hızla değişen teknolojilere yönelmelerinin bir sonucu olarak, Y kuşağı teknolojiyi kendi yaşam tarzlarının bir parçası olarak benimsemiş ve "üçüncü el" ile "İkinci beyin"i temsil etmiştir. Yeni teknolojileri kullanmadaki yatkınlıklarından dolayı Y kuşağı yeni teknolojilerin en öncü ve yoğun kullanıcılarıdırlar (Chuah vd., 2017, 124). Bu kuşağın bazı özellikleri şu şekilde siralanabilir (Sox vd., 2014, 247): Eğlence odaklı; teknoloji ile son derece uyumlu; 
farkında ve güçlü bir topluluk duygusuna sahip; takım oyuncusu; kolay adapte olabilen; interaktif; gurur ve amaç duygusu sahibi olmak. Y kuşağının, teknoloji uygulama ve kullanımı diğer nesillerin önündedir. Y kuşağının teknolojik isteklerini yerine getirmek bu yüzden Y kuşağına hepsinden öncelikli olarak hizmet edecek ve değer kazanacaktır. Bu bağlamda, sanal ortam pazarlama planlamacıları planlama sürecinde Y kuşağının ihtiyaç ve taleplerini dikkate almalıdırlar (Sox vd., 2014, 253).

Farklı nesil gruplarının farklı değerlere, tercihlere ve alışveriş davranışlarına sahip olduğu bu sebeplerden de pazarlamacıların özel ilgi çekici değer önermelerini anlamaları ve bu değerleri benimsetmeleri beklenmektedir (Pariment, 2013, 192). "Kuşak teorisine göre, bir kuşaktan bir bireyin yaşam deneyimlerini paylaşması, kuşaklardakilerin benzer tutum ve inançlar geliştirdiklerini ileri sürmektedir. Bununla birlikte farklı disiplinlerin üyeleri farklı yaşam deneyimlerine ve sosyal bağlamlara sahiptir. Bu nedenle, farklı inançlar, beklentiler ve davranışlar, farklı özellikler geliştirebilir (Chuah vd., 2017, 126). Y kuşağının yaşam tarzları ve harcama alışkanlıkları diğer nesillere göre farklılık arz etmektedir. Y kuşağı artan harcama gücü ile muazzam bir güç olarak ortaya çıkmıştır. Bu kuşağın tercihleri ve ihtiyaçları, özellikle de çevrimiçi pazarlamaya verdikleri yanıtla ilgili olarak, diğer nesillerden farklıdır. Güven, Y kuşağı müșterisi için e-sadakatın en önemli unsurudur. Marka eşitliği aynı zamanda e-sadakatın anahtarıdır. Akış da bu kuşak için önemli bir e-sadakat öncüsüdür. Tüm bu nedenlerle, Y kuşağının diğer nesillerden farklı bir tüketici davranışları ile tutumları olduğu söylenebilir (Bilgihan, 2016, 103). Bu duruma ilişkin olarak, şu örnekler verilebilir: Çin'de çevrimiçi alışveriş yapan kullanıcıların sayısı Haziran 2010'a kadar 142 milyona yükseldi, kullanım oranı \%33.8'e, \%57.0'ye yükseldi ve yarıyılda kullanıcı sayısındaki artış \%31.4'e ulaștı (Jun ve Jaafar, 2011, 123). Lissitsa ve Kol (2016) tarafından yapılan diğer bir çalışmada ise, online alışveriş kapsamında en popüler internet aktiviteleri ve ABD’nin yaklaşık nüfusunun \%80'i elektronik ve turizm harcamaları (uçuşlar, seyahat, oteller) çevrimiçi satın alma biçimde davranış gösterdikleri ortaya çıkmıştır (304). "Euric" isimli kuruluşun Mart ayında 1.500 ABD’li tüketici üzerinde yapmış olduğu araștırma bulgularına göre, Y kuşağının teknolojik değişime daha çabuk ayak uydurduğu, tüm alışverişlerinde teknolojiyi kullanmaya daha fazla meyilli ve perakende deneyimleri konusunda farklı beklentilere sahip olduğu ortaya konulmuştur (Altan, 2018). Kasada bekleme süreleri, envanter bulma durumu ve kolay iade gibi şeyler diğer kuşaklar için öncelikli iken Y kuşağı bu tarz temel perakende becerilerine daha az odaklı durumdadır. Bu durumda Y kuşağı, en büyük tüketici grubu ve önemli satın alma gücüyle pazarlamacıların küresel formattaki en büyük hedef kitlesidir (Pariment, 2013, 190). Pazarlamacılar basit bir satın alma eylemini bir eğlence/veya deneysel bir boyut haline dönüştürmelidirler. Böylece Y kuşağı için bir satın alma seçeneği haline gelmek için, markalar günlük yaşamlarına katma değer katarak, hayatlarının bir parçası haline getirmek zorundadırlar (Lissitsa ve Kol, 2016, 306-311).

Yukarıda sözü edilen araştırmalar ışığında, bu çalışmada Y kuşağı tüketicilerinin internetten alışverișe yönelik tutumlarının belirlenmesi önem arz etmektedir. Çalıșma 2009 yılında Silkü tarafından yapılmış benzer çalışmadan farklı olarak değişen bilgi iletişim teknolojileriyle birlikte pazarlama iletişimi stratejilerindeki değişim ve genç tüketicilerin algılarındaki zamansal değişimin ortaya koyması açısından önem arz etmektedir. 2009 yıllarında tüketiciler daha çok geleneksel pazarlama yöntemleri tercih edilirken günümüz dijital çağında tüketiciyi merkezine 
alan e-ticaret anlayışı ile internetten alışverişi tercih etmektedirler. Bu durumun sebepleri arasında zamansızlık ve hızlı tüketim anlayışı, ucuza kaliteli ürün satın alma isteği ile internetteki ürün çeşitliliği gibi faktörler önde gelmektedir. Geçmiş dönemde internetten alışverişe yönelik güvensizlik probleminin günümüz şartlarında ne şekilde değiştiği ve tüketicinin algı ve satın alma davranışlarının ne yönde değiștiğinin ortaya konulması gereklilik olarak ortaya çıkmaktadır. Ayrıca çalışmanın pazarlama iletişimi alan literatürüne bu yönüyle de katkı sağlayacağı düşünülmektedir. Tüm bu gerekçelerden hareketle, Y kuşağını temsilen Ege Üniversitesi, İletişim Fakültesi, Lisans öğrencilerinin internetten alıșverișe yönelik tutumlarının ne yönde olduğu ve bu durumu etkileyen etmenleri belirlemeye yönelik bir araştırma planlanmıştır. Araştırma sonucu elde edilecek bulgular ışığında öneriler getirilerek pazarlama iletişimi araştırmalarına katkı sağlayacağı düşünülmektedir.

\section{Kavramsal Çerçeve}

\section{Tüketici Davranışları ve Tüketici Davranışlarını Belirleyen Etmenler}

Tüketici davranışı, hangi tür mal ve hizmetlerin kimden, nasıl, nereden ve ne zaman satın alınacağı ya da satın alınıp alınmayacağına ilişkin kişilerin kararlarına ait süreçtir (Walters, 1974). Zikmund ve D’Amico (1995)'a göre ise, istek ve ihtiyaçlarını tatmin etmek amacıyla mal ve hizmet seçimi, satın alma ve kullanmaya yönelik kişisel aktivitelerden oluşan karar verme ve tüketim sürecidir. Günümüzde tüketici davranışını etkileyen pek çok etmen bulunmaktadır. Bu etmenler şu şekilde sıralanabilir (Odabaşı ve Barıș, 20014, 30-36; Gümül, 2015, 20-22):

- Tüketici davranıșı güdülenmiş bir davranıştır; Bir amacı gerçekleștirmek içindir. Tüketici sorunlarına çözüm geliştirmek amacındadır. Ürünler, hizmetler, alışveriş yerleri kişilerin olası çözümleridir. Tüketiciler bu çözümlere ulaşmak için farklı davranışlarda bulunur.

- Tüketici davranışı dinamik bir süreçtir; Tüketici davranışında, satın alma kararı süreci ve bu sürecin hangi boyutlarda neden farklı olduğu ile satın alma sonrasında meydana gelen davranışları inceler.

- Tüketici davranışı çeşitli faaliyetlerden oluşur; Tüketicilerin kararları, deneyimleri ve değerlendirmeleri bulunmaktadır. Tüketici bunların bir kısmını plan ve programlı olarak bir kısmını da tesadüfi olarak yapmaktadır. Örneğin; satış elemanı ile görüşme planlanarak yapılan bir çaba iken reklamları izleme tesadüfi bir çabayı gerektirmektedir.

- Tüketici davranışı karmaşıktır ve zamanlama açısından farklılık gösterir; zamanlama, kararın ne zaman alındığını ve ne kadar süreceğini açıklar.

- Tüketici davranışı farklı roller ile ilgilenir. Satın alma karar sürecinde; başlatıcı, etkileyici, karar verici, satın alıcı ve kullanıcı olmak üzere 5 farklı tüketim rolü mevcuttur. Genel olarak tüketici karar veren birim olarak görülürken aslında bireyden aileye doğru genişleyen bir yelpaze içerisinde görülmelidir.

- Tüketici davranışı çevre faktörlerinden etkilenir; Tüketici davranışının dış faktörlerden etkilenme özelliği, onun hem değișebileceği hem de uyum sağlayacağ bir yapıya sahip olduğunu göstermektedir.

- Tüketici davranışı faklı kişiler için farklılık gösterebilir; Kişisel farklılıkların doğal bir sonucu olarak kabul edilebilir. Tüketiciler farklı tercihlerle farklı satın alma tercihinde bulunabilmektedir. 
Gümül (2015)'e göre, tüketici davranışını belirleyen etmenler; Kişisel faktörler, sosyokültürel faktörler ve psikolojik faktörler olmak üzere üç ana başlıkta toplanmaktadır. Bu faktörler şu șekilde sıralanmaktadır (Gümül, 2015, 22):

- Kişisel Faktörler: Yaş ve Yaşam Dönemi; Cinsiyet; Medeni Durum; Meslek; Gelir Düzeyi; Yaşam Tarzı

- Sosyokültürel Faktörler: Aile; Sosyal Sınıf; Referans Grupları; Kültür

- Psikolojik Faktörler: Güdülenme; Algılama; Öğrenme; İnanç ve Tutum; Kişilik.

Ersoy (2017) çalışmasında ise, tüketici davranışını etkileyen demografik faktörler üzerinde durarak bunların kişiden kişiye değişkenlik gösterdiğini ve bireyin davranışlarını etkilediğini vurgulamaktadır. Örneğin; kişinin yaş aralığı, yaşam tarzı, cinsiyeti, gelir ve eğitim durumu farklılıklar gösterecek dolayısıyla da farklı tercihler yapmalarına sebep olacaktır (Ersoy, 2017, 90). Bu etmenler tüketicilerin davranışlarını ve tutumlarını șekillendirmektedir. Bu bağlamda, bu etmenleri kısaca açıklamak ta araştırmamızın hipotezlerinin oluşturulmasında çatı oluşturması açısından önem arz etmektedir.

\section{Tüketici Davranışını Etkileyen Demografik Faktörler Yaş ve Yaşam Dönemi}

Tüketici davranışını belirlemede yaş değişmeni oldukça önemlidir. Çünkü her yaş grubunun satın aldığg ürün ve hizmet türleri, marka tercihleri, satın alma nedenleri ve biçimleri, bireyleri etkileyen ve harekete geçiren uyaranların neler olduğu açısından farklılık göstermektedir (Elden, 2009, 368). İnsanların ihtiyaçlarını belirlemesi, satın alma davranış biçimleri ile öncelikli ihtiyaçlarının belirlenmesi yaş aralıklarına göre oluşmakta; ürün seçiminde ise yaşla değişen istek ve ihtiyaçlar etkili olmaktadır (Ersoy, 2017, 90). Dolayısıyla her yaş grubunun ihtiyaç ve istek duyduğu ürün ve hizmetler farklıdır (Cemalciler, 1999, 55). Çünkü her yaş grubunun hayat içerisindeki konumuna göre istek, ihtiyaç ve arzuları değişkenlik göstermektedir. Bu durum farklı tüketici davranışlarının ortaya çıkmasına neden olmaktadır. Bazı araștırmacılar, genç yaş kuşağı tüketicilerinin diğer yaş tüketicilerine göre daha fazla satın alma davranışı sergilediğini belirtmektedirler (Helmes vd. 1995, 927-935). Yaşam dönemi ise, demografik yapı ve hayatı değiştiren evlilik, çocuk sahibi olma, ev satın alma, boşanma, çocukların koleje başlaması, gelirin değişmesi, evden taşınma ve emekli olma gibi olaylar sonucu değişmektedir. Yaşam dönemi içerisinde değişimlere uyum sağlama ve anlamaya çalışmak, tüketicinin davranışını da değiștirmektedir. Teknolojik değişimler, zamanın ve insanın hız kazanmasına neden olmakta ve tüm bu oluşumlar yaşam dönemi içerisinde şekillenmektedir (Kotler ve Armstrong, 2012, 145). Bu durumda tüketicilerin yaş farklılıkları ile yaşam tarzlarına ait ihtiyaç ve beklentileri farklılıklar göstermektedir biçiminde yorumlanabilir. Pazarlamacılar bu durumu göz önüne alarak pazarlama iletişimi stratejilerini geliştirmelidirler.

\section{Cinsiyet}

Cinsiyetin tüketici davranışlarına etkisi, kadın ve erkeklerin kendi iç dünyalarından kaynaklanan dünyayı algılama tarzlarındaki farklılıklar nedeniyle satın alma davranışlarında da farklılık göstermesidir (Gümül, 2015, 23). Bazı ürünler yalnızca kadınlar tarafından satın alınırken bazıları ise sadece erkekler tarafından satın alınmaktadır. Örneğin; makyaj ürünleri çoğunlukla kadın tüketiciler tarafından alınan ürünlerdir. Diğer yandan bazı ürünler ise her iki cinsiyet için de farklı özellikleri 
bakımından satın alınabilmektedir. Örneğin; kadınların tercihinde araba rengi daha belirleyici bir unsur olarak ortaya konulurken erkekler için beygir gücü daha büyük önem taşıyabilmektedir (Ersoy, 2017, 91). Sonuç olarak cinsiyet dağılımları ile tercih farklılıkları ya da benzerlikleri pazarı etkileyen bir etmen olarak önemlidir denilebilir.

\section{Meslek ve Eğitim Durumu}

Bir kişinin mesleği ve işi, kullandığı ürünler ve içinde bulunduğu toplumsal sınıf farklılık göstermekte, kişi bu içinde yer aldığı toplumun alt birimlerine göre davranış sergilemektedir. Örneğin; ev hanımı ile genel müdürün ayni giyim ve ayakkabı çeşidine sahip olması genellikle olası bir durum değildir. Dolayısıyla satın aldıkları ve tükettikleri ürünlerden beklentileri de farklı olmaktadır (Ersoy, 2017, 93). Elden (2009)'e göre eğitim düzeyi yüksek ve düşük tüketicilerin davranışlarında da farklılıklar ortaya çıkmaktadır. Örneğin; yüksek eğitim seviyesine sahip tüketiciler sunulan ürünle ilgili karmaşık ve dolaylı anlatımları tercih etmektedir ve bu tür tüketicileri ikna etmek ve yönlendirmek oldukça zordur. Buna karşın düşük eğitim seviyesindeki tüketiciler ise, duygusal uyarıcılardan oluşmuş fazla karışık olmayan mesajları daha kolay anlamakta ve ikna olmaktadırlar (Elden, 2009, 372). Tüketicilerin satın alacakları mal ve hizmetlerin seçiminde eğitim ve öğretimleri ile meslek türleri etkilidir denilebilir. Özetle eğitim seviyesinin yüksekliği ile doğru orantılı olarak kaliteli ürün seçme ile yeni ürünlere yönelim pozitif yönde değişmektedir şeklinde yorumlanabilir.

\section{Medeni Durum}

Tüketici davranış ve alışkanlıklarını etkileyen faktörlerden biridir. Medeni durumu bekar olanların tüketim harcamaları daha çok temel gereksinimler yerine kişisel zevklerine göre oluşturulurken, evli olanlar aile ve çocuk olgusuna göre oluşturmakta ve daha çok birikim davranışı sergilemektedirler (Ersoy, 2017, 93). Bu durum evli, çocuklu olan ailelerin başkalarına karşı sorumluklarından ve önceliklerinden kaynaklıdır. Birey bekar ise kimseye karşı kendisini sorumlu hissetmeden kișisel ihtiyaç ya da arzularını yerine getirerek satın almaktadır. Bağımsız, özgür bir satın alma davranışı göstermektedir denilebilir.

\section{Gelir Düzeyi}

Tüketicinin net geliri onların satın alma gücünü göstermektedir. Kişinin fizyolojik ihtiyaçlarını karşıladıktan sonra elinde kalan gelir "isteğe bağlı gelir" olarak adlandırılmakta ve kendi istediği şekilde kullanma hakkına sahip olmaktadırlar (Ersoy, 2017, 94). Farklı gelir seviyelerindeki bireylerin farklı değerleri, davranışları ve yaşam biçimleri vardır (Göksel vd., 1997, 190). Gelir seviyesindeki farklılıklar, tüketicilerin mağaza ve ürün seçimlerini etkilemektedir. Bu sebeple pazarlamacılar gelir, tasarruf ve faiz oranlarını takip ederek, ürünlerin dizaynını, fiyatını ve konumlandırmalarını gerçekleştirmektedirler (Kotler ve Armstrong, 2012,146). Sonuç olarak, gelir seviyesindeki farklılıklar hem satın alma eyleminde tüketiciyi hem de pazarlama stratejilerini belirlemede pazarlamaciyı etkilemektedir şeklinde yorumlanabilir.

\section{İnternetten Alışveriş İle Tüketicinin Davranış ve Tutumlarıyla İlgili Araştırmalar}

Çevrimiçi alışveriş, geleneksel pazarlama yöntemlerine bir alternatif olarak ortaya çıkmıştır. Ayrıca, bugün internetten alışveriş hızlı büyüyen bir sektördür. 
Bilgisayarların çoğalması, mobil telefonlar ve tabletler de çevrimiçi alışverişin gelişmesine yardımcı olmuştur (Arslan, 2017, 91). İnternet, dönüşüm yaşayan şirketlerle pazarlama da öncülük etmektedir. İnternet tüketici ilişkilerini geliştirmektedir. Ayrıca, şirketler internet sayesinde kişiselleştirilmiş pazarlama uygulamalarını da gerçekleştirebilmektedirler (Gürbüz vd., 2016, 36). Modahl (2001) tüketicilerin internetten alışveriş yapma alışkanlığı edinmelerinin ve kabul etmelerinin itici gücü olarak üç faktörü incelemiştir. Bunlardan ilki; tüketicilerin kariyerlerine verdikleri önemin artması ve işte geçirdikleri zamanın uzamasıyla alışverișe ayırdıkları sürenin azalması; ikinci olarak, tüketicilerin aileleri, arkadaşları ve diğer insanlarla iletişim kurma istekleri; son olarak da internetin bir eğlence aracı olarak görülmesi tüketicilerin internetten alışverişe yönelmelerini sağlamıştır (Yayar ve Sadaklığlu, 2012, 146). İnternet ortamı kullanılarak gerçekleştirilen elektronik alışverişişlemlerinin geleneksel pazarlama ortamından farklı olarak tüketicilere sunduğu hem olumlu hem de olumsuz yönleri bulunmaktadır (Çetin, 2014, 68). İnternetten alışverişin olumlu yönleri; 7/24 istenilen yerden alışveriş imkanı ile ihtiyaca hızlı erişim; Hizmet kalitesindeki artış; Kişiselleștirilmiş ürünleri ucuza mal edebilme; Kişiselleștirilmiş ürünlere kolaylıkla ulaşabilme; Aracıların azalması, daha ucuz ürün ve hizmetler elde edebilme; Ulaşabileceğiniz alan genişliğinin dünya ile sınırlı olması; Ürünlerin karşılaştırmalı analizini yapabilme; Ürün fiyatı araştırmasında oluşacak masrafların ortadan kalkması; Daha fazla ürün çeşidi görerek seçme imkanı yaratması; İhtiyaçlarına uygun ürünü daha kolay bulma imkanı sağlaması; Ürün hakkında ürünü kullananlar tarafından yapılan yorumlar sayesinde ürün hakkında daha net bilgilere sahip olmadır (Çetin, 2014, 68). Çetin $(2014,65)$ Türkiye'deki Üniversitelerde görevli 300 akademisyen üzerinde internet aracılığıyla uyguladığı çalışmasında, en çok tercih edilen alışveriş türünün "indirimli günler" olduğunu, tercih edilen ürünlerde cinsiyet yönünden farklılıklar olduğunu ve internete yönelten etkenlerin "fiyat avantajı", "zamandan tasarruf” ve "ürün çeşitliliği” olduğu şeklinde çarpıcı sonuçlar elde etmiştir. Özgüven (2011, 53-54) çalışmasında, tüketicilerin online alışverişe karşı tutumları ile demografik özellikler arasındaki ilișkiyi incelemiştir. Söz konusu araștırma bulgularına göre, tüketicilerin online alışverişe karşı tutumları kadınlarda erkeklere göre daha yüksektir. Kadınlar, daha fazla online alışverişle ilgilenmekte ve internetten alışveriş yapmaktadırlar. Ayrıca yaş değişkenine göre de, online alışverişi en fazla genç grubun tercih ettiği görülmüștür. Eğitim durumlarına göre lisans ve lisansüstü program mezunu kişiler online alışverişe daha yatkındırlar. Buna karşın gelir seviyeleri bakımından farklılık bulunmamıştır. Benzer bir çalışmayı da, Behdioğlu ve Çilesiz $(2016,15)$ Dumlupınar Üniversitesi öğrencileri üzerinde yapmış ve şu sonuçları elde etmiştir: öğrencilerin online alışveriş sitelerinin seçiminde memnuniyet sağlamalarının gerekliliği ortaya çıkmıştır. Çalışmada, üniversite öğrencilerinin büyük çoğunluğunun iki yıldan fazla bir süredir internetten alışveriş yaptıkları ve sıklıkla "kıyafet ve aksesuar" türü ürünleri internetten satın aldıkları görülmektedir (Behdioğlu ve Çilesiz, 2016, 28). İnternet ilerledikçe, tüketiciler giderek daha fazla bilgi toplar ve çevrimiçi çeşitli ürün ve hizmet satın alırlar. İnternette alışveriş, tüketiciler için fiziksel aktivite gerektirmediği, uzak mesafelere ulaşabildiği ve zaman sınırlaması olmaması gibi nedenlerle tercih edilmesine rağmen hala gizlilik ve güvenlik açısından riskli kabul edilmektedir (Behdioğlu ve Çilesiz, 2016, 16). Çetin $(2014,69)$ internetten alışverişin kullanıcıları için olumsuz yönlerini ise şu 
şekilde sıralamaktadır: İnternetten alışverişin teknik yapısı itibari ile denetime uygun bir niteliği bulunmaması; İnternetten alışveriş işlerinde teknik ve kişisel tedbirler alınmadığından kullanıcıların dolandırılması, aldatılması ve kişisel bilgilerinin çalınması; İnternetten usulsüzlükleri tespit edecek, aşırılıkları ve kural dışı davranışları denetleyip yaptırım uygulayacak merkezi bir otorite bulunmaması; Ancak şikayet üzerine hukuki müdahaleler gerçekleștirilebilmesi; İnternetten alışverişin hukuki alt yapısının ve yaptırım gücünün henüz tam anlamıyla oturtulamamasıdır. Hayran vd $(2017,56)$ internetten alışveriş yapan bireylerin risk algılarını incelemiştir. İnternetten alışverişte tüketicilerin risk algılarının belirlenmesi tüketici davranışlarının anlaşılmasında en önemli ve güçlü bir etmendir. Bu risk algılarına göre; en fazla zaman ve performans riskine özellikle kadınların önem verdikleri görülmüştür. Bu kapsamda, internetten alışverişte ürün deneyememe, ürünün zamanında teslim edilememesi, alışveriş sonrası hizmet yetersizliği ve ek maliyet çıkarılması gibi konularda risk algılarının olduğu ortaya konulmuştur (Hayran vd., 2017, 56). Konuyla ilgili diğer bir çalışmada Yayar ve Sadaklıoğlu $(2012,145)$ tarafından Tokat Valiliği ve Gaziosmanpaşa Üniversitesi'nde çalışan 495 kişi üzerinde internetten ürün satın alma davranışları incelenmiştir. Eğitim ve gelir düzeyi yüksek olan tüketicilerin internetten daha fazla alışveriş yaptıkları saptanmıştır. Buna karşın internetten alışveriş yapmayı engelleyen konular arasında şu faktörler belirlenmiştir; ürün teslimatının gecikmesi ve yapılan reklamların aldatıcı ve yanıltıcı olması. Gümül $(2015,40)^{\prime} u ̈ n$ araştırma sonuçlarına göre ise, tüketicilerin alışveriş yaptıkları sitelere verdikleri kişisel bilgilerin kötü amaçlı kişilerin eline geçeceği endişesi, kredi kartı bilgilerinin çalınması riski ve özellikle bazı ürünlerin internetten satın alınmasının uygun olmaması gibi nedenler tüketicilerin internetten alışveriş yapmaya karşı olumsuz tutum geliştirmesine sebep olmaktadır.

Yukarıda sözü edilen araştırmalar ışı̆̆ında, internetten alışverişin tüketiciler açısından hem olumlu hem de olumsuz yönleri olabilmektedir. Tüketiciler bu durumlara iliş̧in olumlu ya da olumsuz tutum geliştirebilmektedirler. (Gümül, 2015,40 )'e göre, tutumun ürün ve markalara olan talebi yönlendirici olması özelliğinden dolayı, pazarlamacılar tüketicilerde oluşturacakları pozitif duyguları arttırarak ve markaların tüketicilerin kendilerini değerli ve özel hissedecekleri duygular yükleyerek müşteri bağlılı̆̆ını artırabilir. Davis (1989, 320)'a göre kişilerin bilgisayar teknolojilerine ilişkin tutumları algılanan fayda ve algılanan kullanım kolaylığı değişkenlerinden etkilenmektedir. Buna göre algılanan fayda, kullanım kolaylı̆g da tutumu etkilemekte, tutum da niyeti belirlemektedir. Tüketicilerin bilgi teknolojilerini kullanım kolaylığı ile fayda derecesi artması, tüketicilerin internette daha fazla zaman geçirmeleri ve alışveriş yapma niyetlerini de artıracaktır.

$\mathrm{Bu}$ durum, özellikle genç tüketicilerin bilgisayar teknolojilerine olan ilgi ve yatkınlıkları sebebiyle internette daha fazla vakitgeçirmeleri ve internetten alışverişe yapma niyetlerini daha fazla artıracaktır şeklinde yorumlanabilir. Bu duruma ilişkin bir örnek olay üzerinden üniversite gençliğini temsilen bir grup dijital çağ gençliğinin internetten alışverişe yönelik tutumlarının nasıl ve ne yönde değiştiğinin çeşitli demografik özellikler açısından ortaya konulması amaçlanmıştır. Elde edilecek bulgular değerlendirilerek pazarlama iletişimi alanına katkı sağlanacaktır. 


\section{Alan Araştırması}

\section{Y Kuşağını Temsilen Ege Üniversitesi İletişim Fakültesi Halkla İlişkiler ve Tanıtım Bölümü 1. Öğretim Lisans Öğrencilerinin İnternetten Alışverişe Yönelik Tutumlarının Yönünü Belirlemeye Yönelik Analiz}

\section{Araştırmanın Amacı}

$\mathrm{Bu}$ araştırmada amaç, Y kuşağını temsilen E.Ü İletişim Fakültesi 1. Öğretimde okumakta olan lisans öğrencilerinin internetten alışverișe yönelik tutumlarının ne yönde olduğunu tespit etmektir. Bu doğrultuda milenyum kuşağı gençliği olarak da adlandırılan üniversitenin Y kuşağı temsilcilerinin tutumlarının sahip oldukları demografik özelliklere göre farklılık gösterip göstermediği ölçümlenmeye çalışılmıştır.

\section{Araştırmanın Konusu ve Önemi}

Bu araştırmayla E.Ü İletişim Fakültesi 1.öğretimde lisans eğitimi gören öğrencilerin öncelikle demografik özellikleri genel olarak ortaya konulmuştur. Buna ilaveten, öğrencilerin internette pazarlamayla alıșveriș yapma ya da yapmama durumları nedenleriyle tespit edilmeye çalışılmıştır. Son olarak da, Y kuşağının internetten alışverişe yönelik tutumlarının ne yönde değiştiğini ve demografik özelliklerle farklılaşmanın boyutunun "İAYTÖ" ile ölçümlenmesine çalışılmıştır.

\section{Araştırmanın Varsayımları}

- Ege Üniversitesi İletişim Fakültesi 1. Öğretim lisans öğrencilerinin internetten alıșverișe yönelik tutumlarını ölçmeye yönelik ankette yer alan önermeler, söz konusu amaç dâhilinde milenyum gençliğinin ( $\mathrm{Y}$ kuşağı) durumlarını tespit etmek için yeterlidir.

- Uygulanan nicel araștırma yöntemi, araștırmanın amacına, konusuna ve problemlerin çözümüne uygundur.

\section{Araştırmanın Sınırlılıkları}

- Araştırmanın uygulandığı süreçte örneklem biriminin psikolojik ve fizyolojik hali, çevresel koşullar gibi konsantrasyonu bozabilecek her türlü olumsuz koşul araştırmanın sınırlılıklarını oluşturmaktadır.

- Evrenin çok geniş olması araştırmayı sınırlamaktadır.

- Kolayda örnekleme genelleme yapmaya uygun değildir. Örnek büyüklüğü arttırılarak da genelleme gücü arttırılamaz. Bu araştırmanın sınırıdır.

- Zamanın kısıtlı olması araştırmayı sınırlamaktadır.

- Maliyetin fazla olması nedeniyle araştırma sınırlandırılmıştır.

- Araştırma 2018 bahar eğitim-öğretim döneminde uygulanmıștır.

- Araștırma örnek birimini oluşturan E.Ü iletişim Fakültesi 1. Öğretim (Hazırlık sınıfı hariç) Halkla İlişkiler ve Tanıtım, Reklamcılık, Radyo, Televizyon ve Sinema, Gazetecilik Bölümü 1, 2, 3, 4. Sınıf ) 547 kişi ile sınırlıdır.

\section{Araştırma Soruları}

1s: İnternetten pazarlama yoluyla alışveriş yapma durumu ve nedenleri nedir?

2s: İnternetten pazarlama yoluyla alışveriş yapmama durumu ve nedenleri nedir?

3s: İnternetten en çok alışveriş yaptığı ilk üç ürün türü nedir? 
4s: İnternetten en çok alışveriş yaptığı ilk üç ürün türünü tercih etme sebepleri nedir?

5s: İnternette en çok alışveriş yaptığı ilk üç sanal mağazanın adı nedir?

6s: İnternette en çok alışveriş tercih ettikleri ödeme şekli nedir?

\section{Araştırmanın Hipotezleri}

H1: Y kuşağının internetten alışverișe yönelik tutumları bölüm değișkenine göre anlamlı bir farklılık göstermektedir.

H2: Y kuşağının internetten alışverişe yönelik tutumları yaş değişkenine göre anlamlı bir farklılık göstermektedir.

H3: Y kuşağının internetten alışverişe yönelik tutumları cinsiyet değişkenine göre anlamlı bir farklılık göstermektedir.

H4: Y kuşağının internetten alışverişe yönelik tutumları aylık gelir değişkenine göre anlamlı bir farklılık göstermektedir.

H5: Y kuşağının internetten alışverişe yönelik tutumları internetten alışveriş yapma durumları değişkenine göre anlamlı bir farklılık göstermektedir.

H6: Y kuşağının internetten alışverişe yönelik tutumları internetten alışveriş yapma sıklığına göre anlamlı bir farklılık göstermektedir.

H7: Y kuşağının internetten alışverișe yönelik tutumları internetten ürün/hizmet satın alma yılına göre anlamlı bir farklılık göstermektedir.

H8: Y kuşağının internetten alışverişe yönelik tutumları internette alışverişte tercih ettiği ödeme şekline göre anlamlı bir farklılık göstermektedir.

\section{Araştırma Yöntemi}

Çalışmada, günümüzde giderek önem kazanan internetten alışverişi kullanan genç kuşağın tutumunun ne yönde olduğu ortaya konulmaya çalışılacaktır. Bu amaçla nicel yöntem kullanılarak tutumun ne yönde olduğu ortaya konularak, araştırma sorularına ve hipotezlere yanıt aranılacaktır. Veri toplama yöntemi olarak anket tekniği kullanılmıştır.

\section{Araştırmanın Evreni ve Örneklemi}

Araştırmanın çalışma evrenini 2017-2018 öğretim yılı bahar döneminde Ege Üniversitesi İletişim Fakültesi 1.öğretimde öğrenim gören lisans öğrencileri oluşturmaktadır ( $n=1964)$. Hazırlık sınıfı bu evrenin dışında tutulmuştur $(n=5)$. Araştırma evreninden kolayulaşılabilir (uygun) örneklemeyöntemi ile seçilen İletişim Fakültesi Halkla İlişkiler ve Tanıtım ile Reklamcılık bölümlerinden 30'ar; Gazetecilik ve Radyo, Televizyon ve Sinema bölümlerinden en az 35'er kişiye ulaşılmaya çalışılarak toplamda 554 öğrenciyle yüz yüze ortamda anket uygulanmıştır. Eksik ve/veya hatalı doldurduğu anlaşılan anketlerin değerlendirmeden çıkarılmasından sonra 547 kişi örnekleme dahil edilmiştir.

\section{Verilerin Toplanması ve Analizi}

Araştırmada konu, amaç ve sınırlılık göz önüne alınarak veri toplama tekniklerinden nicel yöntem olarak anket uygun görülmüştür. Verileri toplamada, konuyla ilgili literatür taranmış ve tek bir araştırmaya bağlı kalmaksızın "İnternetten Alışverişe Yönelik Tutum Ölçeği” (İAYTÖ) isimli Silkü tarafından 2009 yllında geliștirilen ölçek kullanılmıştır. Silkü (2009) tarafından geliştirilen "İnternetten Alışverişe Yönelik Tutum Ölçeği” (İAYTÖ) ile toplam 15 sorudan oluşan bilgi formu kullanılmıştır. 
Ölçeğe iliş̧in araştırmacı tarafından yapılan ön analiz sonucu Cronbach Alpha güvenilirlik katsayısı $r=.92$ olarak, son analiz sonucu ise $r=.94$ olarak bulunmuştur. Bu değerin oldukça yüksek olduğu ve ölçeğin oldukça güvenilir olduğu söylenebilir. Araştırmacı tarafından yapılan çalışmada ise, Ölçeğe ilişkin geçerlilik KMO=0.956, Cronbach Alpha Güvenirlilik katsayısı r=0.929 olarak bulunmuştur. . Bu değerlere göre, çalışmanın geçerli ve güvenilir olduğu söylenebilir.

\begin{tabular}{|c|c|c|}
\hline \multicolumn{3}{|c|}{ Geçerlilik (KMO and Bartlett's Test) } \\
\hline \multicolumn{2}{|c|}{ Kaiser-Meyer-Olkin Measure of Sampling Adequacy. } & ,956 \\
\hline \multirow[t]{3}{*}{ Bartlett's Test of Sphericity } & Approx. Chi-Square & 6587,054 \\
\hline & df & 351 \\
\hline & Sig. & 000 \\
\hline \multicolumn{3}{|l|}{ Güvenilirlik Analizi } \\
\hline Cronbach's Alpha & $\mathrm{N}$ of Items & \\
\hline ,929 & 27 & \\
\hline
\end{tabular}

Ölçek toplam 27 sorudan oluşmuştur. Ölçekte yer alan maddelerin 16'sı olumlu, 11'i olumsuz ifadeler içermektedir. Ölçekte yer alan olumlu maddeler 5'li dereceleme ile, 5=Tamamen Katılıyorum, 4= Katılıyorum, 3=Kararsızım, 2=Katılmıyorum ve 1= Hiç Katılmıyorum olmak üzere cevaplandırılmaktadır. Ancak 2, 3, 6, 7, 10, 13, 15, 21, 22 , 25 ve 27 numaralı maddeler ters puanlanmaktadır (Tamamen Katılıyorum=1, Hiç Katılmıyorum=5 gibi). Ölçekte en düşük 27, en yüksek 135 (27.5=135) "Tamamen Katılıyorum" seçeneğini seçenlerin puanlarıdır. Katılımcılar maksimum 130 puan almıştır. 3=Kararsızım seçeneğini seçenlerin puanı ise; $27.3=81$ 'dir. $<81$ puandan küçük puanlar, internetten alışverişe yönelik olumsuz tutumu ifade etmektedir. Ölçeğin genel ortalaması $(X=91.55, s=16.206)$ puandır. $\mathrm{Bu}$ puan, internetten alışverişe yönelik olumlu tutumun bir göstergesidir. Verilerin çözümlenmesinde SSPS 25 paket programı kullanılarak, frekans, tek yönlü varyans analizi, t testi, çoklu karşılaștırma testi analizleri yapılmıştır. Önem düzeyi 0.05 olarak ele alınmıştır.

\section{Araştırma Bulguları ve Değerlendirilmesi}

\section{Demografik Bulgular ve Yorumlar}

$\mathrm{Bu}$ bölümde Ege Üniversitesi İletişim Fakültesi 1.öğretimde lisans eğitimi gören öğrencilerin demografik özellikleri ortaya konulmaktadır. Aşağıdaki anket sonuçlarına ilişkin veriler; toplam 554 kişiye uygulanan anket sorularından elde edilen 547 kişinin yanıtlarını kapsamaktadır.

Yapılan incelemede, Y kuşağını temsil eden katılımcılar sırasıyla; \%26.3 (n=144) Gazetecilik, \%26.0 ( $\mathrm{n}=142)$ Halkla İlişkiler ve Tanıtım, \%24.1 ( $\mathrm{n}=132)$ Radyo, Televizyon ve Sinema, \%23.6 (n=129) Reklamcılık bölümlerinden oluşmaktadır. Katılımcıların \%26.3 (n=144)'ü ikinci sınıf, \%25.6 (n=140)'sı dördüncü sınıf, \%24.9 (n=136)'u birinci sınıf ile \%23.2 (n=127)'i üçüncü sınıfta okuyan öğrencilerdir. Öğrencilerin büyük çoğunluğu \%49.9 (n=273)'u (18-21) yaş grubu ile \%45.7 $(n=250)^{\prime} i$ (22-25) yaş grubu oluşturmaktadır. Öğrencilerin \%50.6 (n=277)'sı Kadın, \%49.4 (n=270)'ü Erkek'dir. Gelir gruplarını sırasıyla; \%43.0 (n=235)'ü (501-1000), \%33.3 (n=182)'ü (1001 ve üzeri) ile \%23.8 (n=130)'i (500 ve altı) oluşturmaktadır. Öğrencilerin \%77.7 (n=425)'ini oluşturan büyük bir bölümü internetten alışveriş yaptığı ifade ederken, \%22.3 (n=122)'ü internetten alışveriş yapmadıklarını ifade etmişlerdir. Bu durumun nedenleri araştırıldığında aşağıdaki yanıtlar elde edilmiştir. 


\section{Araştırma Sorularına İlişkin Bulgular ve Yorumlar}

1s: İnternetten pazarlama yoluyla alışveriş yapma durumu ve nedenleri nedir? Sorusu açık uçlu olarak sorularak, katılımcıların yanıtları birebir aşağıda aktarılmaktadır.

Öğrencilerin \%77.70 (n=425)'i “Evet” internetten alışveriş yapıyorum şeklinde ifade etmişlerdir.

Y kuşağı internetten alışveriş yapma nedenleri olarak şu cevapları ifade etmişlerdir: "ucuzluk, indirim, hesapl, ekonomik ve zahmetsiz; kolay ve avantajll, daha pratik, ürüne ulaşım kolaylığı, hızlı olduğu için; bazı ürünleri almanın tek yolu; fiyat aralığı aradığım üründe daha geniş oluyor ve bu da bana ayni ürünü X mağazası ve diğer şirketler ve kaliteli ürünlere ulaşma kolaylığı; daha fazla seçenek sunması; ürün araştırma süresini kısaltması, ürün araştırma niteliğini arttırması, oturulan yerden ürün karşılaştırmaya olanak tanıması; uzaktan yakına getirmek; üșendiğim için; gezmek zorunda kalmamak; mağazada bulamadığım ya da dışarı çıkma durumum olmadığında internet üzerinden alışveriş yaparım; güvenilir olması; bulunmayan ender yurtdışı ürünler; ikinci el ürünler almak; kampanyaları uygun buluyorum ve beğendiğim ürünleri oluyor" şeklinde ifade etmişlerdir.

2s: İnternetten pazarlama yoluyla alışveriş yapmama durumu ve nedenleri nedir? Sorusu açık uçlu olarak sorularak, katılımcıların yanıtları birebir aşağıda aktarılmaktadır.

Öğrencilerin \%22.3 (n=122)'ü "Hayır" internetten alışveriş yapmıyorum şeklinde ifade etmiştir.

Y kuşağı internette alışveriş yapmama nedenlerini şu şekilde ifade etmişlerdir:

“Güvenilir bulmuyorum; Gelecek malın sağlamlığı ve kalitesi hakkında endișeli olmam; Kart bilgilerimin çalınacağından endişe ediyorum; Genelde vaat edildiği şekilde gelmeyeceğinden korkuyorum. Yapan arkadaşlarımın başına geldiğine şahit oldum; Ürünlerin orijinal olmaması ihtimalinden dolayı yapmıyorum; ürün değişimi problemleri konusunda sıkıntılar yașayacağımı düşünüyorum; ürünün geç gelme durumu; deneyerek görerek almama durumu; Alınan ürünün bozuk, uygun olmadığı takdirde değişimin uğraştırıyor olması; Dokunarak, görerek, deneyerek alışveriş yapmayı seviyorum; Görüntü ile gelen sipariş uymamaktadır; Geleneksel alışveriş yöntemini daha tatmin edici buluyorum; Kargoyla ilgili sıkıntı yaşamak istemiyorum; Kredi kartıyla alışveriş yapmaya güvenmiyorum; Kararsızım; Tüketimi sevmiyorum; Gerek duymuyorum; Bilgisayarım yok; Kredi kartımın olmaması; Büyükşehirde yaşadığım için istediğim her ürüne zaten rahatlıkla ulaşabiliyorum. $O$ yüzden internetten alışveriş yapmıyorum" şeklinde ifade etmişlerdir.

3s: İnternetten en çok alışveriş yaptığı ilk üç ürün türü nedir? Sorusu açık uçlu olarak sorularak, katılımcıların yanıtları birebir aşağıda aktarılmaktadır.

Y kuşağı internette alışveriş yaptığı ilk üç ürün türünü şu şekilde ifade etmişlerdir: \%57.4 (n=314) "Giysi, ayakkabı, spor giysiler", \%35.5 (n=194) "Elektronik, cd", \%31.1 (n=170) "Kitap", \%21.8 (n=119) "Aksesuar, takl, dekor", \%14.8 (n=81) "Bakım, makyaj, temizlik", \%9.1 (n=50) "Vitamin, besin takviyesi, gıda", \%5.3 (n=29) "Eğlence, bilet, hediye, oyuncak", \%5.3 (n=29) "Diğer", \%3.8 (n=21) "seyahat" olarak ifade etmiştir. Bu duruma göre birinciliği "giysi, ayakkabı, spor giysiler", ikinciliği, "Elektronik-cd", üçüncülüğü ise, "Kitap" izlemektedir. Bu durum Y kuşağı gençliğinin 
internetten alışveriş yaparak giyindikleri, eğlendikleri ve okudukları şeklinde yorumlanabilir. İnternetin hayatımıza girmesiyle birlikte geleneksel alışveriş alışkanlıkların da değiştiğinin en önemli göstergesi olarak karşımıza çıkmaktadır. Bu duruma ilişkin olarak, Türkiye İstatistik Kurumu'nun (TUİK) verileri, internet üzerinden alışveriş yapan bireylerin \%65.2'sinin giyim ve spor malzemesi satın aldığını ortaya koymaktadır (CNN, 2018). Buna göre özellikle teknoloji içinde doğan Y kuşağı gençliğinin geleneksel alışveriş ortamlarından uzaklaşarak internet ortamlarına yöneldiklerinin bir göstergesidir denilebilir.

4s: İnternetten en çok alışveriş yaptığı ilk üç ürün türünü tercih etme sebepleri nedir? Sorusu açık uçlu olarak sorularak, katılımcıların yanıtları birebir aşağıda aktarılmaktadır.

Öğrencilerin \%74.2 (n=406)'sı internetten alışverișimde ürün türü tercih etme sebebim "Var" şeklinde ifade etmiştir.

Y kuşağı İnternetten alışveriş yaptığı ilk üç ürünü tercih etme sebebini şu şekilde ifade etmişlerdir:

"Evden çıkmak zor geldiği için; Kampanya/kampanya imkanları fazla olduğu için; Bu ürünlerin kalitesi değişmez nereden olduğunun bir önemi yok; Sezon öncesi ürünler internete daha önce düşüyor mağazada bulunmayan kitap veya ürün olduğu için; Spor ve bilgisayar ürünlerini mağazalardan almaya korkuyorum daha pahalıya denk gelir; daha çok çeşit sunması; çoğunlukla fiziksel yerine dijital hizmet almayı tercih etmem; Çok fazla ürün çeșidi ve karşılaştırma imkanı. Hediye ve kozmetikte de internette daha çok çeşide ulaşabiliyorum; Kitaplar daha uygun fiyatta oluyor; zaman azlığı ve cazip firsatlar; kolay ve güvenilir siteler olduğu için; modeller yurt dışından geliyor ve sadece internette var; bir konuşan satış elemanı yok; Geri iade edebileceğimi bildiğim için olmazsa gönderirim diye düşünüyorum; Belli markaların, belli ürünlerinin kaliteleri her şekilde ve her yerde standart olduğu için hem güvenli, hem de daha kolay bir alışveriş sağlıyor; Şikayetler ise dikkate alınıp kendilerini geliştirmektedir; global bir piyasa ve rekabete ulaşım imkanı; Bilet satış yerine gitmektense internetten almayı tercih ediyorum; Bedenime uygun olanları yalnız sitelerde bulabildiğim için; Mağazada kafamın karışmasını istemiyorum; Aynı zamanda mağaza mağaza gezip aradığımı bulamamak gibi bir sonuçla karşılaşmıyorum; Promosyonlar ve kampanyalardan dolayı ve geniş ürün yelpazesi; Spesifik konularda ya da az sayıda basılmış kitapları internette bulabiliyorum. Bunun dıșında bazı yayınevleri ön sipariște indirim yapabiliyor; Genellikle ne alacă̆ımı bilmiyorum. Internette gezerken ihtiyacım olanı fark ediyorum; Tüm Türkiye'ye ve Dünyaya erişimi kolay” şeklinde ifade etmişlerdir.

5s: İnternette en çok alışveriş yaptığı ilk üç sanal mağazanın adı nedir? Sorusuna katılımcıların yanıtları aşağıda yer almaktadır.

Y kuşağı İnternette en çok alışveriş yaptığı ilk üç sanal mağaza adını şu şekilde ifade etmişlerdir:

“\%44.6 (n=244) ile "Diğer", \%24.7 (n=135) ile "Trendyol", \%22.9 (n=123)'u "Hepsiburada”, \%15.0 (n=82)'i “N11", \%12.4 (n=68)' ü “Gitti Gidiyor”, \%11.2 (n=61)'si “Ali Express", \%9.3 (n=51)'ü “İdefix", \%9.1 (n=50)'i “Kitapyurdu”ile \%9.1 (n=50)'i "DR", \%5.9 (n=32)'u "YemekSepeti” ve \%2.4 (n=13)'ü “Steam” şeklinde ifade etmişlerdir.

Öğrencilerin \%69.8 (n=382)'i internetten en çok tercih ettiği sanal mağaza adına "Evet/Var" şeklinde ifade etmiştir. 
Y kuşağı İnternetten alışveriş en çok tercih ettiği sanal mağaza adını söyleme sebebini şu şekilde ifade etmişlerdir:

"Güvenli, hızl, kaliteli; pratik; ekonomik; ödeme sistemleri; basit içerikli; ürün çeşitliliği fazla; ürün ve güncel stoklar var; kullanışlı ve çok seçenekli; aradığım ürünleri bu sitelerde bulabiliyorum; mağaza gezmenin zor gelmesi; Bana uygun beden ve fiyatlara sahip; kampanyalardan dolayı, vs." şeklinde ifade etmişlerdir.

6s: İnternette en çok alışveriş tercih ettikleri ödeme şekli nedir? Sorusuna katılımcıların yanıtları aşağıda yer almaktadır.

Y kuşağı İnternette en çok alışveriş tercih ettikleri ödeme şeklini şu şekilde ifade etmişlerdir:

Katılımcıların \%49.7 (n=272)'i “Kredi Kartı”, \%21.2 (n=116)'si “Her Íkisini Birlikte”, \%6.8 (n=37)'i “Nakit/Kapıda Ödeme" șeklinde yanıtlarken, \%22.3 (n=122)'i ise "Alışveriş Yapmıyorum" şeklinde yanıt vermişlerdir. Bu duruma göre öğrencilerin yarıya yakın bölümü ile büyük bir çoğunluğunun internette kredi kartı ile ödenmeyi tercih ettiklerini göstermektedir. Bu durum özellikle günümüzde bankaların sanal kart uygulamalarını getirmeleri ve sınırlı para limitiyle tüketicilerin daha güvenilir bir ortamda alışverișe yönlendirmeleri tercih sebebi olabileceğini düşündürmektedir.

\section{Araştırma Hipotezlerine İlişkin Bulgular ve Yorumlar}

Skewness (Çarpıklık): -0.634; Kurtosis (Bakınlık)=0.761.

Skewness (Çarpıklık) ve Kurtosis (Baskınlık) değerlerinin +2.0 ile -2.0 arasında olduğu görülmektedir. Değerlerin +2.0 ile -2.0 arasında olması verilerimizin normal dağılımına uyduğunun göstergesidir (Geoge\&Mallery, 2010). Bu yüzden verilerin analizinde parametrik testler kullanılmıştır.

H1: Y kuşağının internetten alışverişe yönelik tutumları bölüm değişkenine göre anlamlı bir farklılık göstermektedir.

Y kuşağının internetten alışverişe yönelik tutumlarının bölümlere göre incelenmesinde, tek yönlü varyans analizi tekniği ile çoklu karşılaştırma testi yapılmıştır. Bu duruma ilişkin sonuçlar Tablo 1'de verilmektedir.

Tablo 1: Y Kuşağının Bölümlere Göre İnternetten Alışverişe Yönelik Tutum Puanları

\begin{tabular}{|c|c|c|c|c|c|}
\hline Bölümler & $\mathbf{n}$ & $\mathbf{x}$ & $\mathbf{s}$ & $\mathbf{F}$ & $\mathbf{p}^{\star}$ \\
\hline Ніт & 142 & 92.38 & 14.33 & \multirow{4}{*}{4.634} & \multirow{4}{*}{$.003^{\star}$} \\
\hline Gazetecilik & 144 & 88.97 & 17.95 & & \\
\hline RTS & 132 & 89.63 & 17.02 & & \\
\hline Reklamcilık & 129 & 95.52 & 14.48 & & \\
\hline
\end{tabular}

Tablo 1'de görüldüğü gibi, Reklamcılık bölümünün tutum puanları (X=95.52) en yüksek, Gazetecilik bölümünün tutum puanları (X=88.97) en düşük olmakla birlikte, internetten alışverişe yönelik tutum puanları istatistiksel açıdan anlamlı bir biçimde değişmektedir ( $F=4.64, p=.003)$. Gazetecilik bölümü ile Reklamcılık bölümü arasında ( $\mathrm{p}=.004)$ ve Radyo, Televizyon ve Sinema bölümü ile Reklamcılık bölümü arasında ( $p=.017)$ farklılıklar vardır. Bu durum Reklamcılık bölümü öğrencilerinin internetten alışverișe yönelik tutumlarının Gazetecilik ve Radyo, Televizyon ve Sinema bölümü öğrencilerin tutumlarına göre daha olumlu olduğunu şeklinde yorumlanabilir. 
H2: Y kuşağının internetten alışverişe yönelik tutumları yaş değişkenine göre anlamlı bir farklılık göstermektedir.

Y kuşağının internetten alışverişe yönelik tutumlarının yaşlara göre incelenmesinde tek yönlü varyans analizi tekniği ile çoklu karşılaştırma testi ile hangi değişkenler arasında fark olduğu tespit edilmiştir. Buna göre öğrencilerin internetten alışverișe yönelik tutum puanları istatistiksel olarak yaş grupları arasında anlamlı bir farklılık vardır ( $\mathrm{F}=3.513, \mathrm{p}=.015)$. Tablo 2'de bu duruma ilişkin sonuçlar verilmektedir.

Tablo 2: Y Kuşağının Yaș Gruplarına Göre İnternetten Alıșverișe Yönelik Tutum Puanları

\begin{tabular}{|l|c|c|c|c|c|}
\hline Yaş Grupları & $\mathbf{n}$ & $\mathbf{X}$ & $\mathbf{S}$ & $\mathbf{F}$ & $\mathbf{p}^{*}$ \\
\hline$(18-21)$ & 273 & 89.77 & 16.46 & & \\
\cline { 1 - 4 }$(22-25)$ & 250 & 93.93 & 15.37 & & \\
\cline { 1 - 4 }$(26-29)$ & 14 & 87.58 & 22.12 & & $.015^{\star}$ \\
\cline { 1 - 4 }$(30$ ve üzeri) & 10 & 86.81 & 14.05 & & \\
\hline$p^{*}<.05$
\end{tabular}

Tablo2'den de anlaşılacağı gibi, (22-25) yaş grubu öğrencilerin tutum puanları $(X=93.93)$ en yüksek iken (30 ve üzeri) yaş grubu öğrencilerin tutum puanları ( $\mathrm{X}=86.81$ ) düşük olmakla birlikte, internetten alışverişe yönelik tutum puanları istatistiksel açıdan anlamlı bir biçimde değişmektedir ( $\mathrm{F}=3.513, \mathrm{p}=.015)$. (22-25) yaş grubu ile (18-21) yaș grubu arasında ( $\mathrm{p}=.017)$ farklılık vardır. Bu durum (22-25) yaș grubu öğrenciler (18-21) yaş grubu öğrencilere göre internetten alışverişe yönelik tutumları daha olumludur şeklinde yorumlanabilir. Bu durumda yaşın internetten alışverişe yönelik tutum üzerinde etkili olduğunu düşündürmektedir. Özellikle üniversiteye yeni başlamış öğrencilerin bu pazarlama yöntemine daha temkinli yaklaştıkları buna karşın üniversiteye adaptasyon sürecini geçiren gençlerin, İletişim Fakültesi eğitim-öğretim ders programında "Pazarlama”, "Doğrudan Pazarlama” gibi alan dersleri aldıktan sonra düşüncelerinin değiştiğini ve internetten alışverișe yönelik daha olumlu tutum geliştirdikleri şeklinde yorumlanabilir.

H3: Y kuşağının internetten alışverişe yönelik tutumları cinsiyete göre anlamlı bir farklılık göstermektedir.

Y kuşağının internetten alışverişe yönelik tutumlarının cinsiyete göre incelenmiş ve istatistiksel olarak 0.05 düzeyinde anlamlı bir farklılık bulunmuştur. Y kuşağının internetten alışverișe yönelik tutumları cinsiyete göre incelenmesinde $t$ testi yapılmış ve sonuçlar Tablo 3'de verilmiştir.

Tablo 3: Y Kuşağının Cinsiyete Göre İnternetten Alışverişe Yönelik Tutum Puanları

\begin{tabular}{|l|c|c|c|c|c|}
\hline Cinsiyet & $\mathbf{n}$ & $\mathbf{x}$ & $\mathbf{s}$ & $\mathbf{t}$ & $\mathbf{p}^{*}$ \\
\hline Kız & 277 & 90.06 & 15.93 & & \multirow{2}{*}{-2.194} \\
\cline { 1 - 4 } Erkek & 270 & 93.09 & 16.38 & & \\
\hline$p^{*}<.05$ &
\end{tabular}

Tablo 3'de görüldüğü üzere, göreli olarak erkek öğrencilerin tutum puanları (X=93.09), kız öğrencilerin tutum puanlarına ( $X=90.06)$ göre kısmen daha yüksektir ve internetten alışverişe yönelik tutumlar cinsiyete göre istatiksel açıdan 0.05 düzeyinde anlamlı bir farklılık vardır ( $\mathrm{t}=-2.194, \mathrm{p}=0.029)$. Bu durum erkek öğrencilerin lehinedir. Diğer bir ifadeyle erkek öğrenciler internetten alışverișe daha olumlu yaklaşmaktadır denilebilir. Türkiye İstatistik Kurumu'nun (TUİK) verilerine de göre, internet-bilgisayar oranları (16-74) yaş grubu erkeklerde \%68.6 ve \%80.4 
iken, kadınlarda \%50.6 ve \%65.6'dır. İnternet üzerinden kişisel kullanım amacıyla mal ve hizmet siparişi veren ya da satın alan bireylerin oranı, \%29.3 olmuştur. Bir önceki yılda bu oran \%24.9 idi (CNN, 2018). (Dennis vd., 2010) çalışmasına göre, erkekler çevrimiçi alışverişler de dahil olmak üzere bir çok amaç için internetin daha hırslı kullanıcısıdırlar. Sullivan ve Heitmeyer (2008), erkeklerin kadınlara göre hem internete hem de bilgisayara karşı daha olumlu tutumları olduğunu ifade etmektedir (285). Bu durum erkeklerin bilgi iletişim teknolojilerine ilgileriyle ve genetik yatkınlıklarıyla ilişkilendirilebilir. Özellikle dijital çağın içerisinde doğan Y kuşağı erkeklerin teknolojiye uyumları ve kullanabilirlikleri geçmiş dönemde doğan erkeklere göre daha hızlıdır. İnternet çağı gençlerinin mal ve hizmet satın alma ya da satma konusunda interneti her geçen gün daha etkin kullandıkları söylenebilir. Bu durumun aksi olarak, Silkü $(2009,2291)$ 'ün “İletişim Fakültesi Öğrencilerinin Internetten Alışverişe Yönelik Tutumları" isimli çalışmasında ise, erkek öğrencilerin internetten alışveriş tutum puanları kız öğrencilerin internetten alışveriş tutum puanlarına göre kısmen daha yüksek bulunmasına rağmen istatistiksel açıdan aralarında farklılık bulunmamıştır. Bu durum, araştırmanın yapıldığg yılda internette alışverişin çok yeni bir pazarlama yöntemi olarak kullanılmaya başlaması ve bir takım ön yargılarla her iki cinsiyet grubunun olumsuz tutum sergilemesinin nedeni olabileceğini düşündürmektedir.

H4: Y kuşağının internetten alışverişe yönelik tutumları aylık gelir değişkenine göre anlamlı bir farklılık göstermektedir.

Y kuşağının internetten alışverişe yönelik tutumlarının aylık gelir değişkeni arasında anlamlı bir farklılık vardır. Y kuşağının internetten alışverişe yönelik tutumları aylık gelir durumlarına göre $\mathrm{F}$ testi yapılmış ve Anova analizi ile incelenmiş ve sonuçlar Tablo 4'de yer almıştır.

Tablo 4: Y Kuşağının Aylık Gelir Durumlarına Göre Internetten Alışverişe Yönelik Tutum Puanları

\begin{tabular}{|c|c|c|c|c|c|}
\hline Aylık Gelir Durumu & $\mathbf{n}$ & $\mathbf{x}$ & $\mathbf{s}$ & $\mathbf{F}$ & $\mathbf{p}^{\star}$ \\
\hline 500 ve Altı & 130 & 88.44 & 16.16 & \multirow{3}{*}{5.180} & \multirow{3}{*}{$.006^{*}$} \\
\hline 501 ve 1000 & 235 & 91.16 & 16.08 & & \\
\hline 1001 ve üzeri & 182 & 94.31 & 16.03 & & \\
\hline
\end{tabular}

Tablo 4'de görüldüğü üzere, göreli olarak (1001 ve üzeri) aylık gelir grubuna sahip öğrencilerin tutum puanları (X=94.31), (500 ve Altı) aylık gelir grubuna sahip öğrencilerin tutum puanlarına $(X=88.44)$ göre daha yüksektir ve internetten alışverişe yönelik tutumlar aylık grubuna göre istatistiksel açıdan 0.05 düzeyinde anlamlı bir farklılık vardır ( $\mathrm{F}=5.180, \mathrm{p}=0.006)$. Buna göre, (500 ve Altı) aylık gelir grubu ile (1001 ve üzeri) aylık gelir grubuna sahip öğrenciler arasında $(p=.004)$ farklılık vardır. Bu duruma göre öğrencilerin aylık gelir seviyesi yükseldikçe internetten alışverişe yönelik tutumları daha olumlu olduğu şeklinde yorumlanabilir.

H5: Y kuşağının internetten alışverişe yönelik tutumları internetten alışveriş yapma durumlarına göre anlamlı bir farklılık göstermektedir.

Y kuşağının internetten alışverişe yönelik tutumları internetten alışveriş yapma durumuna göre incelenmesinde t testi yapılmış ve sonuçlar Tablo 5'de verilmiştir. 
Tablo 5: Y Kuşağının İnternetten Alışveriş Yapma Durumlarına

Göre Internetten Alışverişe Yönelik Tutum Puanları

\begin{tabular}{|l|c|c|c|c|c|}
\hline $\begin{array}{l}\text { Internetten Alışveriş } \\
\text { Yapma Durumları }\end{array}$ & $\mathbf{n}$ & $\mathbf{x}$ & $\mathbf{s}$ & $\mathbf{t}$ & \multirow{2}{*}{$\mathbf{p}^{\star}$} \\
\hline Evet & 425 & 97.48 & 11.17 & \multirow{2}{*}{21.77} & $0.032^{*}$ \\
\hline Hayır & 122 & 70.95 & 14.03 & & \\
\hline$p^{*}<.05$ &
\end{tabular}

Tablo 5'de görüldüğü gibi, öğrencilerin internetten alışverişe yönelik durumları "Evet" diyenlerin tutum puanları (X=97.48), "Hayır diyenlerin tutum puanlarından $(\mathrm{X}=70.95)$ daha yüksektir ve internetten alışveriş yapma durumlarına göre istatistiksel açıdan 0.05 düzeyinde anlamlı bir farklılık vardır $(\mathrm{t}=21.772, \mathrm{p}=0.032)$. $\mathrm{Bu}$ durumda internetten alışveriş yapanların internetten alışverișe yönelik daha olumlu tutum geliştirdikleri şeklinde yorumlanabilir. Silkü (2009) tarafından yapılan benzer bir çalışmada da bu durum desteklenmektedir. Diğer çalışmaya göre yapılan çalışmada olumlu tutum değerinin yükseldiği görülmektedir. Bu durumu değișen pazarlama yöntemlerinde internetten alışverişe yönelik bakış açısının günümüzde öneminin arttığının ve pozitif yönde geliştiğinin bir sonucu olabilir.

H6: Y kuşağının internetten alışverişe yönelik tutumları internetten alışveriş yapma sıklığına göre anlamlı bir farklılık göstermektedir.

Y kuşağının internetten alışverişe yönelik tutumları internetten alışveriş yapma sıklıklarına göre incelenmiş ve sonuçlar Tablo 6'da verilmiştir.

Tablo 6: Y Kuşağının İnternetten Alışveriş Yapma Sıklıklarına

Göre Internetten Alışverişe Yönelik Tutum Puanları

\begin{tabular}{|l|c|c|c|c|c|}
\hline \begin{tabular}{l|c|c|c|} 
Internetten Alısveriş \\
Yapma Sıklıkları
\end{tabular} & $\mathbf{n}$ & $\mathbf{x}$ & $\mathbf{~}$ & $\mathbf{F}$ & \multirow{2}{*}{$\mathbf{p}^{*}$} \\
\hline Yok/Hiç & 122 & 70.87 & 13.99 & & \\
\cline { 1 - 4 } 1-2 defa & 60 & 90.64 & 8.08 & \multirow{2}{*}{183.232} & \multirow{2}{*}{$.000^{*}$} \\
\hline 3-5 defa & 99 & 95.18 & 10.33 & & \\
\hline 6 defa ve üstü & 266 & 99.91 & 11.20 & & \\
\hline$p^{*}<.05$ &
\end{tabular}

Tablo 6'da görüldügü üzere, (6 defa ve üstü) sıklıkta internetten alışveriş yapan öğrencilerin tutum puanları (X=99.91) diğerlerine göre en yüksektir. İnternetten hiç alışveriş yapmayanların tutum puanları $(X=70.87)$ ile (3-5 defa) alışveriş yapanların tutum puanları $(X=95.18)$ ve $(1-2$ defa $)(X=90.64)$ alışveriş yapanların tutum puanları istatistiksel açıdan 0.05 düzeyinde anlamlı bir biçimde değişmektedir $(\mathrm{F}=183.232, \mathrm{p}=.000)$.

İnternetten hiç alışveriş yapmam diyenlerle internetten alışveriş yaparım diyen diğerleri arasında anlamlı bir farklılık vardır. (1-2 defa) ile ( 6 defa ve üzeri) ( $p=.000$ ) ve (3-5 defa) ile (6 defa ve üzeri) ( $\mathrm{p}=.0003$ ) arasında farklılık bulunmuştur. Bu farklılık (6 defa ve üzeri) sıklıkta internetten alışveriş yapan öğrencilerin lehinedir. Buna göre alışveriş sıklığı arttıkça öğrencilerin internetten alışverişe yönelik daha olumlu tutum sergilediklerinin bir göstergesidir şeklinde yorumlanabilir. Silkü (2009)'nün yapmış olduğu çalıșmanın bulguları bu sonucu desteklemektedir (2297). Söz konusu çalışmada da internetten (6 defa ve üstü) alışveriş yapan öğrencilerin diğer öğrencilere göre internetten alışverișe yönelik tutumları daha olumlu yöndedir. Buna göre, internetten alışverişe yönelik olumlu tutuma sahip olanların daha fazla internetten alışverişe yöneldikleri șeklinde de yorumlanabilir. 
H7: Y kuşağının internetten alışverişe yönelik tutumları internetten ürün/hizmet satın alma yılına göre anlamlı bir farklılık göstermektedir.

Y kuşağının internetten alışverişe yönelik tutumları internetten ürün/hizmet satın alma yıllarına göre incelenmiş ve sonuçlar Tablo 7'de verilmiştir.

Tablo 7: Y Kuşağının İnternetten Alışveriş̧ Yapma Durumları Yillara

Göre Internetten Alışverișe Yönelik Tutum Puanları

\begin{tabular}{|c|c|c|c|c|c|}
\hline $\begin{array}{l}\text { İnternetten Ürün/Hizmet } \\
\text { Satın AIma Yılları }\end{array}$ & n & $\mathbf{x}$ & $\mathbf{s}$ & $\mathbf{F}$ & $\mathbf{p}^{*}$ \\
\hline Yok/Hiç & 122 & 72.99 & 14.01 & \multirow{5}{*}{138.72} & \multirow{5}{*}{$.000^{\star}$} \\
\hline 1 yıldan daha az & 33 & 92.66 & 9.77 & & \\
\hline $1-3$ yıl & 219 & 97.70 & 11.02 & & \\
\hline 4-6 yıl & 133 & 102.00 & 10.37 & & \\
\hline 7 yıldan daha fazla & 40 & 108.02 & 10.74 & & \\
\hline
\end{tabular}

Tablo 7'de görüldüğü üzere, göreli olarak (7 yıldan daha fazla) internetten ürün/ hizmet satın alan öğrencilerin tutum puanları $(X=108.02)$ en yüksek iken hiç internetten ürün/hizmet satın almayan öğrencilerin tutum puanları $(X=72.99)$ en düşüktür ve internetten alışverișe yönelik tutum puanları istatistiksel açıdan anlamlı bir biçimde değişmektedir ( $\mathrm{F}=138.723, \mathrm{p}=.000)$.

(1 yıldan daha az) ve (1-3 yıl) internetten ürün/hizmet satın alan öğrenciler arasında $(\mathrm{p}=.140)$ anlamlı bir farklılık yoktur. Diğer tüm gruplar arasında istatistiksel açıdan 0.05 düzeyinde anlamlı bir farklılık vardır. Bu farklılık (7 yıldan daha fazla) internetten ürün/hizmet satın alan öğrencilerin lehinedir. Bu durum, öğrencilerin internetten ürün/hizmet satın alma yılı arttıkça internetten alışverişe yönelik daha olumlu tutum geliştirdikleri şeklinde yorumlanabilir.

H8: Y kuşağının internetten alışverișe yönelik tutumları internette alışveriște tercih ettiği ödeme şekline göre anlamlı bir farklılık göstermektedir.

Y kuşağının internetten alışverişe yönelik tutumlarının alışveriş ödeme tercihi şekline göre irdelenmiş ve istatistiksel olarak 0.005 düzeyinde anlamlı bir farklılık bulunmuştur ( $\mathrm{F}=165.757$, p=.000). Söz konusu bulgular Tablo 8'de verilmektedir.

Tablo 8: Y Kuşağının İnternetten Alışveriș Ödeme Tercihi Şekline

Göre Internetten Alışverişe Yönelik Tutum Puanları

\begin{tabular}{|l|c|c|c|c|c|}
\hline Alışveriş Ödeme Tercihi Şekli & $\mathbf{n}$ & $\mathbf{x}$ & $\mathbf{s}$ & $\mathbf{F}$ & \multirow{2}{*}{$\mathbf{p}^{*}$} \\
\hline Nakit/Kapıda Ödeme & 37 & 94.09 & 9.65 & & \\
\cline { 1 - 4 } Kredi Kartı İle & 272 & 100.30 & 11.49 & \multirow{3}{*}{165.757} & \multirow{2}{*}{$.000^{*}$} \\
\cline { 1 - 4 } Her İkisini Birlikte & 115 & 100.01 & 10.85 & & \\
\cline { 1 - 4 } Alışveriş Yapmıyor & 122 & 72.96 & 13.97 & & \\
\hline$p^{*}<.05$ & & &
\end{tabular}

Tablo 8'de görüldüğü üzere, öğrencilerin internetten alışverişe yönelik tutumları, alışveriş ödeme tercihi şekline göre farklılaşmaktadır. $\mathrm{Bu}$ farklılık, internetten alışveriş yapmayanlar ile internetten alışveriş yapanlar arasındadır $(p=.000) . \mathrm{Bu}$ farklılık "Nakit/Kapıda Ödeme" șekli ile "Kredi Kartı İle" ( $\mathrm{p}=.02)$ ve "Her İkisini Birlikte" ( $\mathrm{p}=.05)$ ödeme şeklini tercih edenler arasında ve "Kredi Kartı İle" ödeme tercihi şekli ile "Nakit/Kapıda Ödeme" ( $p=.02)$ ödeme tercihi arasında ve "Her İkisini Birlikte" ödeme tercihi ile "Nakit/Kapıda ödeme" tercihi $(\mathrm{p}=.05)$ arasındadır. Bu 
durum, “Kredi Kartı ile” ödeme tercihi alışveriş yapanlar lehinedir. Diğer bir deyişle, internetten alışveriște "Kredi Kartı İle" ödemeyi tercih eden öğrencilerin internetten alışverişe yönelik olumlu tutuma sahip oldukları görülmektedir. Bu durum "Kredi Kartı İle" ödeme şeklini en çok kullanan öğrencilerin internetten alışverişe daha sıcak baktıkları ve daha olumlu tutum geliștirdikleri şeklinde yorumlanabilir. $\mathrm{Bu}$ durum, Silkü (2009)'un araștırma bulgularıyla paralellik göstermektedir. Söz konusu çalışmada da "Kredi Kartı İle" alışveriş yapanların "Peşin/Nakit" ödeyenlere göre daha olumlu tutum sergiledikleri görülmüștür. Bu durum, özellikle son yıllardaki bankacılık hizmetlerinin bireyin kişisel bilgilerini korumaya yönelik sanal kart uygulamalarının müşterilerde güven duygusu yaratması şeklinde yorumlanabilir.

\section{Sonuç ve Öneriler}

Y kuşağını temsil eden İletişim Fakültesi lisans öğrencilerinin internetten alışverișe yönelik tutumları ile bunu etkileyen etmenleri belirlemeyi amaçlayan bu araştırmada, öğrencilerin internetten alışverişe yönelik tutumları olumlu bulunmuştur. Y kuşağını temsil eden İletişim Fakültesi lisans öğrencilerinin internetten alışverișe yönelik tutumları; bölümlere, yaşa, cinsiyete, aylık gelir durumuna, internetten alışveriş yapma durumuna, internetten alışveriş yapma sıklığına, internetten ürün/hizmet satın alma yılına, alıșveriș ödeme tercih şekline göre pozitif yönde değișmektedir.

Y kuşağını temsil eden İletişim Fakültesi öğrencilerinin demografik özelliklerine ait sonuçlar şunlardır:

- Anket katılımcılarının çoğu kadınlardan oluşmaktadır (\%50.6).

- (18-21) yaş grubunda yer alan öğrenciler çoğunluğu oluşturmaktadır (\%49.9).

- Katılımcıların çoğunu Gazetecilik bölümü öğrencileri oluşturmaktadır (\%26.3).

- 2.sınıf öğrenciler büyük çoğunluğu oluşturmaktadır (\%26.3).

- Katılımcıların büyük çoğunluğu (501-1000 arası) aylık gelir seviyesine sahiptir (\%43.0).

Araştırma sorularına ilişkin sonuçlar şunlardır:

- İnternetten alışveriş yapan öğrenciler büyük çoğunluğu oluşturmaktadır (\%77.7).

- Y kuşağı gençliği internetten alışveriş yapma nedeni olarak; "Fiyat uygunluğu, ürün çeşitliliği, kalite, ulaşım kolaylığı, hız, güvenilirlik ve kampanyaları sıralamıştır (\%77.7).

- İnternetten alışveriş yapmayan öğrenciler yapanlara göre daha düşük orandadir (\%22.3).

- Y kuşağı gençliğinin internetten alışveriş yapmama nedeni olarak; “Güvensizlik, ürünü görmeme ve deneyememe, ürün kalitesi hakkındaki endișe, ürün değişimdeki problemler, kredi kartı bilgilerinin çalınması korkusu, gerek duymama, vs." cevaplar sıralanmıştır (\%22.3).

- Katılımcıların \%57.4 ile büyük bir çoğunluğu; "Giysi, ayakkabı, spor giysiler" gibi ürünleri internetten satın almaktadır.

- Y kuşağının internetten satın almayı tercih ettiğim ürünler var şeklinde yanıt verenler \%74.2'lik büyük bir çoğunluğu oluşturmaktadır. Bu durumun nedeni olarak; "Promosyonlar, kampanyalar, indirimler, kalite, kolay ulaşım, ürün çeşidi, vakit kaybetmemek, hız, vs." şeklinde ifade etmişlerdir. 
- Gençlerin en çok tercih ettikleri sanal mağaza adı "Var" yanıtı \%69.8 oranındadır. Bu mağazanın ismi olarak \%44.6 ile "Diğer" seçeneği ile karma yanıt vermişlerdir.

- Y kuşağı gençliği internetten en fazla kredi kartı ile alışveriş yapmaktadır (\%49.7).

Araştırmanın hipotezlerine ilişkin sonuçlar şunlardır:

- Y kuşağının internetten alışverişe yönelik tutumları bölümlere göre anlamlı farklılık göstermektedir. $\mathrm{Bu}$ farklılığın Reklamcılık bölümü öğrencilerinin Gazetecilik ve Radyo, Televizyon ve Sinema bölümü öğrencilerine göre daha yüksek tutum puanlarına sahip oldukları ve olumlu tutum sergiledikleri söylenebilir (Hipotez 1 kabul edilmiştir).

- Y kuşağı gençliğinin internetten alışverișe yönelik tutumları yaş gruplarına göre anlamlı bir farklılık göstermektedir. Bu ilișkinin (22-25) yaş grubu ile (18-21) yaş grubu arasında olduğu görülmektedir. Buna göre (22-25) yaş grubu öğrencileri (18-21) yaş grubu öğrencilerine göre internetten alışverișe yönelik daha olumlu tutum sergilemektedir ( $\mathrm{F}=3.513, \mathrm{p}=.015)$. (Hipotez 2 kabul edilmiştir).

- Y kuşağının internetten alışverişe yönelik tutumları cinsiyet değişkenine göre anlamlı farklılık göstermektedir. Bu farklılığın; erkek öğrencilerin internette yönelik tutumlarının kadın öğrencilerinkine göre daha yüksek olduğu söylenebilir. (Hipotez 3 kabul edilmiştir).

- Y kuşağının internetten alışverişe yönelik tutumları aylık gelir durumlarına göre anlamlı bir farklılık göstermektedir. Bu ilişkinin (1001 ve üzeri) ile (500 ve Altı) aylık gelir grupları arasında olduğu görülmektedir. Buna göre aylık gelir seviyesi arttıkça internetten alışverişe yönelik tutum puanlarının da arttığ öğrencilerin olumlu tutum geliştirdikleri şeklinde yorumlanabilir (Hipotez 4 kabul edilmiştir).

- Y kuşağının internetten alışverișe yönelik tutumları internetten alışveriş yapma durumlarına göre anlamlı bir farklılık göstermektedir. Bu ilişkinin internetten alışveriş yapanlarla yapmayanlar arasında olduğu görülmektedir. Buna göre internetten alışveriş yapanların yapmayanlara göre daha olumlu tutum gösterdikleri söylenebilir (Hipotez 5 kabul edilmiştir).

- Y kuşağının internetten alışverişe yönelik tutumları internetten alışveriş yapma sıklıklarına göre anlamlı farklılık göstermektedir. Bu ilişkinin (6 defa ve üzeri) ile (1-2 defa) ve (3-5 defa) alışveriş yapanlar arasında olduğu görülmektedir ve ayrıca gençlerin internetten alışveriş sıklığı arttıkça internetten alışverişe yönelik daha olumlu tutum geliştirdikleri söylenebilir (Hipotez 6 kabul edilmiştir).

- Y kuşağının internetten alışverişe yönelik tutumları internetten ürün/hizmet satın alma yıllarına göre anlamlı farklılık göstermektedir. Bu farklılığın (7 yıldan daha fazla) internetten alışveriş yapan öğrenciler ile diğer yıllar alışveriş yapan öğrencilere göre daha yüksek olduğu görülmektedir. Buna göre, internetten ürün/hizmet satın alma yılı arttıkça öğrencilerin olumlu tutum geliştirdikleri söylenebilir (Hipotez 7 kabul edilmiştir).

- Y kuşağının internetten alışverişe yönelik tutumları internette alışverişte tercih ettiği ödeme şekline göre anlamlı farklılık göstermektedir. Bu ilişki "Kredi Kartı İle" alışveriş yapan öğrenciler lehinedir. Buna göre, internette alışverişte kredi kartı ile ödemeyi tercih eden gençlerin internette alışverişe daha olumlu yaklaştıkları söylenebilir (Hipotez 8 kabul edilmiștir). 
Özetle; Y kuşağının gençlerinin internetten alışverişe yönelik tutumları ile tüm değişkenler arasında anlamlı bir ilişki ortaya çıkmıştır. Buna göre araștırma hipotezlerinin tümü (H1, H2, H3, H4, H5, H6, H7, H8) kabul edilmiştir. Buna göre Y kuşağının internetten alışverişe yönelik tutum puanlarının: bölüm, yaş, cinsiyet, aylık gelir, internetten alışveriş yapma durumları, alışveriş sıklıkları, satın alma yılları ve tercih ettikleri ödeme şekillerine göre pozitif yönde değiștiği görülmektedir. Bu bağlamda, Y kușağını temsilen İletişim Fakültesi öğrencilerinin internetten alışverișe yönelik tutumlarının olumlu olduğu söylenebilir. Silkü (2009)’nün yapmış olduğu çalışmada ise, bu durumun aksine, gençler internetten alışverişe yönelik olumsuz tutum sergilemiş̧lerdir. Bu durumun en önemli sebebi olarak, değişen bilgi iletişim teknolojileriyle birlikte milenyum gençliği olarak da adlandırılan Y kuşağının teknoloji dünyası içerisinde doğmasından kaynaklanabileceğini düşündürmektedir. $\mathrm{X}$ kuşağı gibi teknoloji ile sonradan adapte olmak yerine dünyaya geldiklerinde pek çok teknolojik uyaranla etkileşmektedirler. Ayrıca (2009)'dan günümüze kadar pazarlama dünyasında da değişim ve dijital pazarlamaya dönüşüm söz konusudur. "e-pazarlama”, “dijital pazarlama”, Doğrudan pazarlama" ve "internetten pazarlama" gibi pek çok pazarlama yöntem ve araçları kullanılmaya başlanmıştır. Bu durum tüketicilerin de daha bilgili, bilinçli ve farkındalıklı olmalarını yaratmıştır. Yıllar içerisinde pek çok işletme, pazarlama amaçlı internet ortamını yöntem ya da bir araç olarak kullanmaya başlamıştır. Bu durumunun en önemli nedenleri olarak; maliyetin düşük olması, kolay kullanım özelliği, hızı ve ürün çeşitliliği ile birlikte de tüketiciler tarafından tercih edilebilirliğini arttırmıștır. Son yıllarda güvensizlik problemini de işletmelerin gizlilik teminatlarıyla aşmış ve internete yönelik olumlu tutum sergilemeye başlamışlardır. Bu değişim araştırma bulgularının pozitif yönde değișmesi sonucunu ortaya koymuştur.

Tüm bu elde edilen bulgular neticesinde şu öneriler sunulabilir:

- Güvensizlik sebebiyle internetten alışveriş yapmayan gençlere yönelik bilgilendirmeler yapılarak güvenirliliği arttırılabilir.

- Kadın katılımcıların internete yönelik olumlu tutumlarını daha da yükseltmek amacıyla kadın tüketicilerin ilgisini çekebilecek içerikte web sayfa tasarımlarına gidilebilir.

- Benzer çalışmaların farklı örneklem gruplarında tekrar edilmesi.

- Farklı araștırma yöntemleri ile Y kuşağının satın alma kararı sürecini etkileyen faktörlerin ortaya konulması bunların tutum üzerindeki etkilerinin araştırılması.

- Y kuşağı ile X, Z ve Baby Boomers kuşaklarının internetten alışverișe yönelik tutumlarının ne yönde değiștiği karşılaștırmalı analizlerle araștırılarak nedenlerin tespit edilmesi önerilir.

\section{Kaynakça}

Altan, S. (2018). Y Kuşağl, Alışveriş Teknolojilerini En Aktif Kullanan Kuşak, Pazarlamasyon Dergisi, Erişim: 09.11.2018, http://www.pazarlamasyon. com/perakende/y-kusagi-alisveris-teknolojilerini-en-aktif-kullanan-kusak/

Arslan, E. (2017). The Perceptions of the Customers Staying at Hotels towards Online Shopping, Selçuk Üniversitesi Sosyal ve Teknik Araştırmalar Dergisi, 13, 90-98.

Behdioğlu, S., ve Çilesiz, N. (2016). Evaluation of Attributes of Online Shopping Sites with Kano Model, Sosyal Bilimler Dergisi, ICEBSS Özel Sayısı, 15-30. 
Bilgihan, A. (2016). Gen Y Customer Loyalty in Online Shopping: An Integrated Model of Trust, User Experience and Branding, Computers in Human Behavior, Science Direct, 61, 103-113, Erișim: 09.11.2018, www.elsevier.com/.

Bulunmaz, B. (2016). Gelișen Teknolojileriyle Birlikte Değișen Pazarlama Yöntemleri ve Dijital Pazarlama. TRT Akademi Dijital Medya Sayısı, Cilt: 1, Sayı: 2.

Cemalciler, İ. (1999). Pazarlama Kavramlar Kararlar, İstanbul: Beta.

Chuah, S. H., Marimuthu, M., Kandampully, J. ve Bilgihan, A. (2017). What Drives Gen Y Loyalty? Understanding the Mediated Moderating Roles of Switching Costs and Alternative Attractiveness in the Value-Satisfaction-Loyalty Chain, Journal of Retailing and Consumer Services, 36, 124-136, Erişim: 09.11.2018, www.elsevier.com/locate/jretconser.

CNN (2018). Erişim: 09.11.2018, https://www.cnnturk.com/ekonomi /turkiye/ internet-üzerinden-alışverş-orani-yükeliyor.

Corodeanu, D.T.A. (2015). Consumer's Protection from the Generation Y's Perspective. A Research Based on Scenarios, Procedia Economics and Finance, 20, 8-18, Erişim: 09.11.2018, www.elsevier.com/locate/procedia. www.sciencedirect. com.

Çetin, H. (2014). Online (Çevrimiçi) Alışverişte Akademisyen Davranışları ve Alışverișe Yönelten Etkenler, Süleyman Demirel Üniversitesi İktisadi ve İdari Bilimler Fakültesi Dergisi, C: 19, 65-76.

Davis, F. D. (1989). Perceived Usefulness, Perceived Ease of Use and User Acceptance of Information Technology, MS Quarterly, 13(3), 319-340.

Dennis, C., Alesia, M., Tin, W. L. ve Chanaka, J. (2010). The Influence of Social E-Shopping in Enhancing Young Women's Online Shopping Behavior, Journal of Customer Behaviour, 9 (2), 151-174.

Elden, M. (2009). Reklam ve Reklamcilık, İstanbul: Say.

Erdoğan, Z. ve Torun, T. (2009). Bir İlişkisel Pazarlama Aracı olarak Sanal Topluluklar, Pazarlama ve Pazarlama Araştırmaları Dergisi, Sayı:4, 45-71.

Ersoy, E. (2017). Tüketicilerin Değişen Alışveriş Alışkanlıkları (Online Alışveriş), İletişim Çalışmaları Dergisi, 3(4), 87-129.

George, D. ve Mallery, P. (2010). SPSS for Windows Step by Step: A Simple Guide and Reference 17.0 Update (10th Edition b.). Boston: Pearson.

Göksel, A. Bülent, Kocabaş, F., Elden, M. (1997). Pazarlama İletişimi Açısından Halkla İlişkiler ve Reklam, İstanbul.

Gül, H. ve Boz, M. (2012). İnternet Ortamında Pazarlama, Online Rezervasyon: Şehirlerarası Otobüs Firmaları Üzerine Bir Araştırma, IUYD, 3 (1).

Gümül, F. (2015). Tüketicilerin İnternetten Alışveriş Davranışlarını Etkileyen Faktörler (Yüksek Lisans Tezi), Yüzüncü Yıl Üniversitesi Sosyal Bilimler Enstitüsü İşletme Anabilim Dalı, Van.

Gürbüz, A., Kılıç, İ., Yeğin, T. (2016). Effects of Remarketing Implementations on Consumers' Behaviour, International Journal of Research in Management, Economics and Commerce, 6(7), 36-45. 
Hayran, S., Gül, A., Duru, S. (2017). Türkiye'de İnternetten Alışveriş Yapan Bireylerin Risk Algılarının Cinsiyet Farklılıklarına Göre Değerlendirilmesi, Electronic Journal of Vocational Colleges, 3(7), 48-57.

Helmes, K. F., Young, S. N., Pihl, R. O. (1995). Assesment of Measures of Impulsivity in Healty Male Volunteers, Personality and Individud Differences, 19 (6), 925935.

Hoffman, D. L. ve Novak, T. (1995). Commercial Scenarios fort he Web: Opportunies and Challenges, Journal of Computer-Mediated Communication, Vol 1, No:3.

Jun, G. ve Jaafar, N. I. (2011). A Study on Comsumers' Attitude Towards Online Shopping in China, International Journal of Business and Social Science, Vol:2, No: 22, 122-132, Erişim: 09.11.2018, www.ijbssnet.com.

Jusoh Md. Z., ve Ling, G. H. (2012). Factors Influencing Consumers' Attitude Towards E-Commerce Purchases Through Online Shopping, Internetional Journal of Hummanities and Social Science, Vol: 2, No: 4, Special ISSUE, 223-230.

Kotler, P. ve Armstrong, G. (2012). Principles of Marketing, New Jersey: Prentice Hall.

Lagrosen, S. (2005). Effects of the Internet on the Marketing Communication of Service Companies, Journal of Services Marketing, 19 (2), 63-69.

Lissitsa, S. ve Kol, O. (2016). Generation X vs Generation Y-A Decade of Online Shopping, Journal of Retailing and Consumer Services, Vol: 31, 304-312, Erişim: 09.11.2018, https://doi.org/10.1016/j.retconser.2016.04.015.

Modahl, M. (2001). Now or Never: How Companies Must Change Today to Win the Battle for Internet Consumers. New York: Harper Collions 10 East Third Street, 1st ed.

Nadeem, W., Andreini, D., Salo, J. ve Laukkanen, T. (2015). Engaging Consumers Online Through Websites and Social Media: A Gender Study of Italian Generation Y Clothing Consumers, International Journal of Information Management, 35, 432-442, Erişim: 09.11.2018, www.elsevier.com/

Odabaşı, Y., Gülfidan, B. (2014). Tüketici Davranışı, İstanbul: Mediacat Yayınları.

Özcan, S. O. (2010). İnternet Pazarlama Faaliyetlerinde Tüketici Satın Alma Karar Süreci, IUYD, 1 (2).

Özgüven, N. (2011). Tüketicilerin Online Alışverișe Karşı Tutumları İle Demografik Özellikleri Arasındaki İlişkinin Analizi, KMÜ Sosyal ve Ekonomik Araştırmalar Dergisi, 13(21), 47-54.

Pariment, A. (2013). Generation Y vs Baby Boomers: Shopping Behavior, Buyer Involvement and Implications for Retailing, Journal of Retailing and Consumer Services, Elsevier, 20, 189-199, Erişim: 09.11.2018, www.elsevier.com/ locate/jretconser.

Silkü, H.A. (2009). İletişim Fakültesi Öğrencilerinin İnternetten Alışverișe Yönelik Tutumları, Journal of Yaşar University, 4(15), 2281-2301, Erişim: 09.11.2018, http://joy.yasar.edu.tr 
Sox, C. B., Kline, S. F. ve Crews, T. B. (2014). Identifying Best Practices, Opportunities and Barriers in Meeting Planning for Generation Y, International Journal of Hospitality Management, Science Direct, 36, 224-254, Erişim: 09.11.2018, www.elsevier.com/locate/ijhosman.

Sullivan, P. ve Heitmeyer, J. (2008). Looking at Gen Y Shopping Prefences and Intentions: Exploring The Role of Experience and Apparel Involvement, International Journal of Consumer Studies, Vol. 32, 3, 285-295, Oxford (u.a.): Blackwell Science, ISSN1470-6423, 2db-1d 2045 1891.-

Tağıyev, R. (2005). E-Ticaret ve İnternet Üzerinden Pazarlama (Yüksek Lisans Tezi), Ankara Üniversitesi Sosyal Bilimler Enstitüsü İşletme Anabilim Dalı, Ankara.

Timmers, P. (2000). Electronic Commerce: Strategies and Models for Business-tobusiness Trading, Wiley, Chichester.

Walters, C.G. (1974). Consumer Behavior Theory and Practice. Illionois: Richard D. Irwin.

Yayar, R. ve Sadaklığlu, H. (2012). Kamu Çalışanlarının İnternetten Ürün Satın Alma Davranışları Üzerine Bir Araştırma, Business and Economics Research Journal, 3 (3), 145-157. www.berjournal.com.

Zikmund, G. W., D’amico, M. (1995). Effective Marketing, St Paul: West Publishing. 